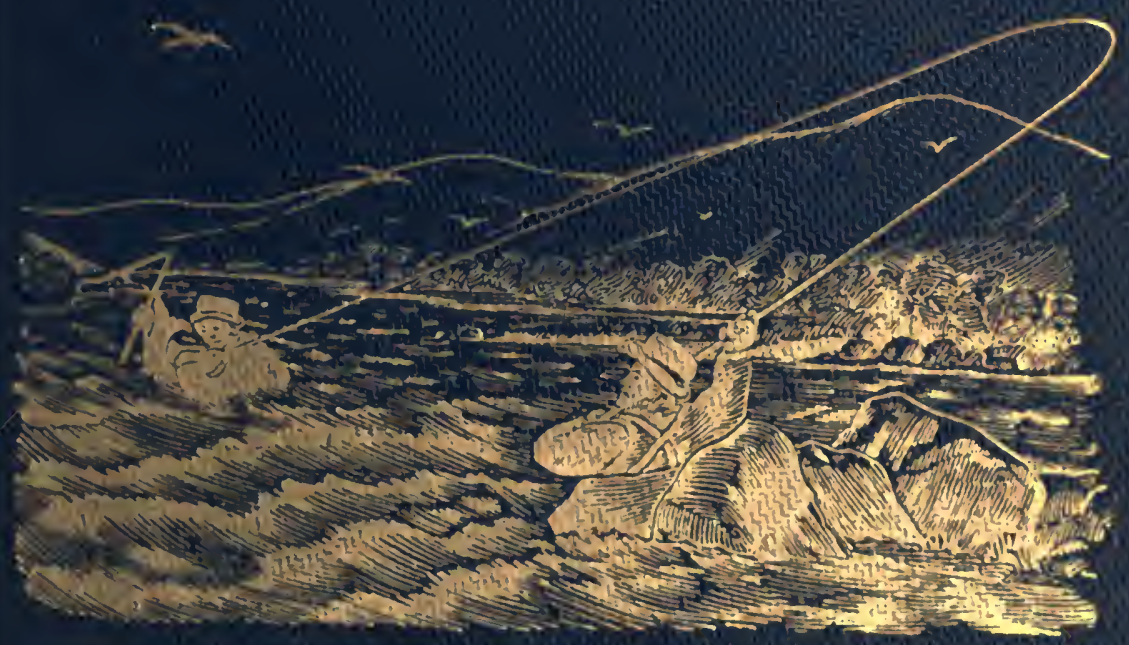

ornia

al 


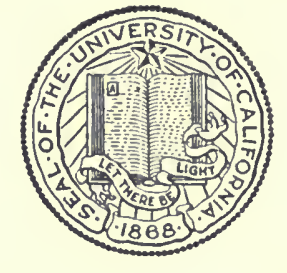

\section{THE LIBRARY OF}

\section{THE UNIVERSITY OF CALIFORNIA LOS ANGELES}




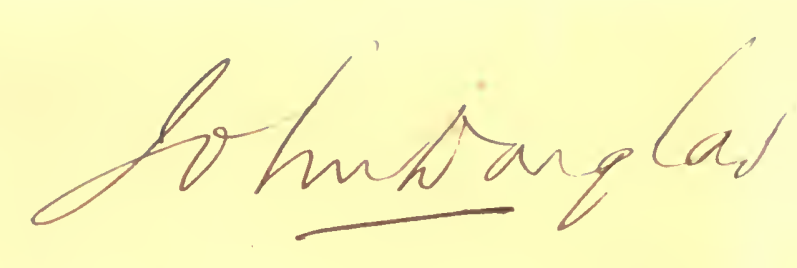


Digitized by the Internet Archive in 2007 with funding from Microsoft Corporation 



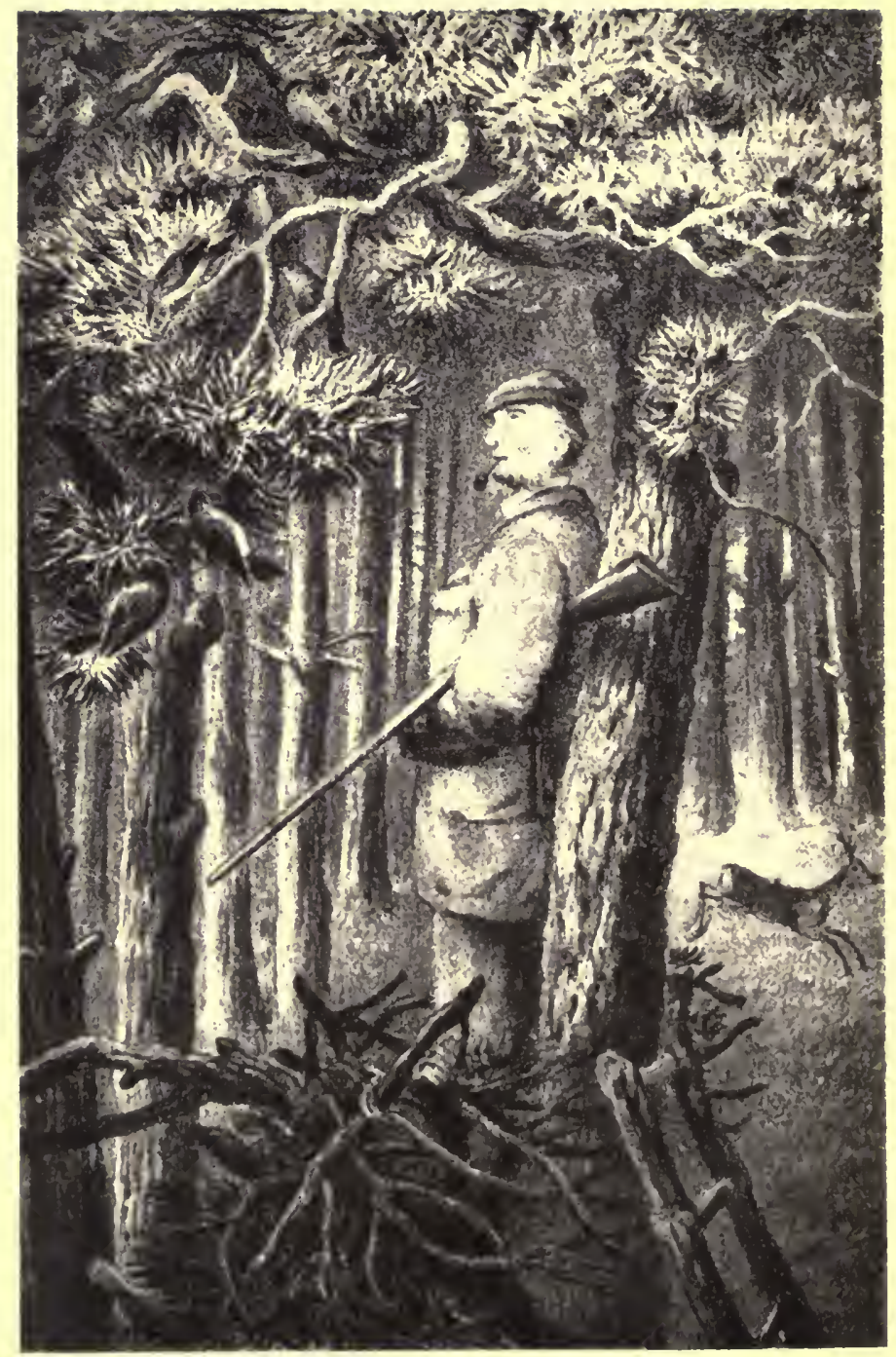

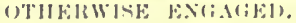




\section{AUT'UMNS ON THE SPEY.}

(B)

A. E. KNOX, M.A., F.L.S.

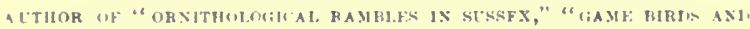

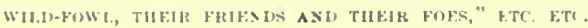

15 ITH FUIR ULLOTKA7WIS BI UILF

I, I) N DU N :

.OHN VAN VOORET, PATERYOSTER ROW. $\operatorname{Micect.x\times 11}$ 
Losines)

PhINTEI, BY WOODFALL ANI KIXIHEL. MITHOR, IAXE, STRAN1, W.'.

- 
SK
189
K $77 a$

71

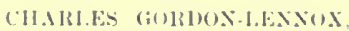

(iт⿰丿) 1) KE () R RCHMOND, K.(i..

ETC, I.TK

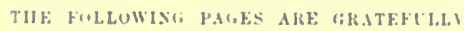
inscriber.

62971 



\section{PREFACE.}

Tne greater part of this little volume is derived from letters written, on the spur of the moment, to friends in the South, during sereral autumes passed by the author at Gordon Castle. He rentures to hope that some of its pages may possess an interest for the field naturalist as well as for the salmon-fisher. 



\section{CONTENTS.}

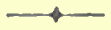

$\Lambda$ Bind's-ete liew of the Riter. . . . . 1

$\Lambda$ Disaprontshest . . . . . . . . . . 13

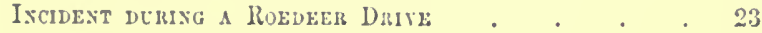

$\Lambda$ Friexd in NeEd . . . . . . . . 37

Frrat Nature . . . . . . . 48

Siey Flígs am Wabisg Gear . . . . . . 61

A BLAXK DaY is a DeEn Foresz . . . . . 78

Floods ox the Spes, axd litraside Fuol . • . 95

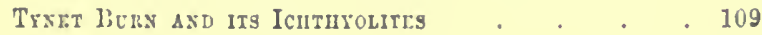

Alt DERG . . . . . . . . . . . 127

BIRDS . . . . . . . . . . 134

Capture of a leviatha. . . . . . . 158 



\title{
AUTUMNS ON THE SPEY.
}

\section{A BIRD'S-EYE VIEW OF THE RIVER.}

\author{
"The river nobly foams and flows, \\ The charm of this enchanted ground, \\ And all its thousand turns disclose \\ Some fresher beauty varying round: \\ The haughtiest breast its wish might bouml \\ Throngh life to dwell delighted here ; \\ Nor coulit on earth a spot be found \\ To nature and to me so dear."
}

Brros.

Artuorgin most of the scenes and incidents described in the following papers have reference to that portion of the Spey which includes the last twelve miles of its rapid passagre to the ocean, ret perhaps a rougl sketch of its entire career, from its Highland cralle to its funl disappearance in the North Sea-a distance of alout a hundred miles-may not he matceptable to the realer.

The spey, then, rises in a small hoch, more than 1200 feet above the level of the ocean, in the 
district of Lochaber, among lofty precipitous mountains. This insignificant sheet of water, little more than a quarter of a mile in length, and considerably less in breadth, is the undoubted source of this glorious river; and although several tributaries fall into the parent stream, yet none are sufficiently important to deserve a higher title. During its early career, the surrounding hills are bleak, barren, and comparatively uninteresting, but where the new Highland railway crosses it, a few miles before reaching Kingussic, they assume a different character; and the traveller, while sitting at his ease in a coupe of the Limited Mail train, may enjoy for many miles one of the finest panoramic views of romantic seenery that the British Islands ean afford. On the northwest the long chain of the Monadliadh-or grey -mountains stretches away into the distance. On the south-east rise the still loftier and grander Grampians, with Ben Mel)hui and Cairngorm, and other giants of the group, cupped occasionally, even at this season, with snow. Gradually the hills on either side diminish, as they aprroneh the river, until they terminate in an extensive valley advaneing towards the north, through which the Spey meanders for many milas in the midst of most magnificent scenery. Several small lakes 
occasionally stud the face of the landscape, with, here and there, an old ruin perehed on an island; the lesser hills that rise from their banks being clothed with evergreen fir-woods, while deep glens, covered with heather and surmounted by rocky peaks, fringed with birch-trees, sueceed ench other in endless variety, as the train rushes along. On reaching Kinrara, all these elements of the picturesque are seen to perfection. The rocks beeome wilder, and as if thrown about in confusion by a Titan's hand, and the birch woods denser and more extensive; lut every now and then, open prairic-like glades, dotted with elumps of timber trees, appear as if by magric, and give a dash of civilization to the seenery. Beyond this the Spey may still be seen, winding between its rocky banks, and farther off the woods of Rothiemurehus clothing the liils in the middle of the picture, which, as the riew reecdes, become higher and higher, until the eye rests at last on the dark belts of perennially green pine forests, and beyond these again the irregular outline of the (irampians encloses the distant landscape.

After passing Grantown, the railway, which has hitherto nearly allhered to the direction of the old Ilighland road, finally deserts the neighbourhood of the river and pursues a north-western 
course, while that of the latter is about northnorth-east. It thus flows through the celebrated Strathspey, passing Cromdale-which signifies crooked plain, from the semicircular sweep that the Spey takes close by the church and manse.* For several miles the hills forming the banks of the river are elothed with forests of pine, larch, and oak: its elevation here is about 600 feet above the sea.

A great variety of scenery follows for many miles. Well-wooded hills, cultivated farms, sandy plains, and barren heaths, sueceed each other. Soon afterwards the Aven, the most important tributary of the Spey, falls in on the eastern side. The latter now progresses for many miles amidst pieturesque scenery in the immediate neighbourhood of its course, passing near Ballindalloch, Carron, Wester Elchies, and Aberlour.

At Craigellachie the road rums close to the river, at the base of a precipitous bank clothed with firtrees, which, in some portions of the rock, seem to have fixed their roots in the deep fissures of the granite. Between this and Arndilly, on the eastern bank, the Fiddich pours its tributary waters into the Spey, and the lofty hill of Ben Aigen appears, and forms the backerround of the pietnre

- I)r. Lusganeir's Spryside. 
for many miles. Here the river turns to the left, and after making a semicireular sweep throngh the plain of Rothes, approaches "the pass of Surdon," but apparently is compelled by this promontory, which is only 237 feet from the opposite hill, to ehange its direction more to the north, which it pursues with little deviation during the remainder of its course.

Soon afterwards the Spey reaches " Boat o" Brig," where, as the name implies, there was formerly a ferry-boat; but the water is now spamed, not only by the riaduet of the Aberdeen and Inverness Railway, 245 feet in length, but by a suspension bridge, a little higher up. This bridge was erected after the memorithle floods of 1829 , which committed such terrible derastation in this part of Scotland, as to realize one's notions of almost the worst part of the Noachim deluge.

I have now attempted a hasty sketch of the progress of the river, from its origin in the little mountain turn in Lochaber to Boat o' Brig. 'The distance from this to "The 'Tugnet," near Garmouth, where it diseharges itsclf into the sea, is between ten and twelve miles.

Hitherto the course of the spey has been through the heart of the Higlilands, among strata of primeval structure, showing the result of central up- 
heaval, in the highest degree, among the craggy mountains of the Grampians, whose peaks and precipices are composed of granite, gneiss, schist, quartz-rock, porphyry, and other erystalline masses, associated with limestone and micaceous slates. The very plains and valleys are the result of extreme denudation, and impress one with the conviction that the whole of this district was once under the sea. Even the old red sandstone seems to have been washed away, leaving the Silurian system, with its gneissose rocks, flagstones, and clays on the surface, or only covered by the comparatively recent glacial drift, or " till," which indeed prevails throughout all this part of Scotland. On reaching that portion of the river where I commeneed this digression, we seem first to touch the immer edge of the long belt of old red sandstone that bounds the whole of the Moray Firth, from near the mouth of the Spey in a sonthwestem direction, advaneing up the Caledonian Canal nearly twenty miles further than Inverness, and from that town again towards the north-east, along the const of Ross-shire, including Cromarty and Dornoch firths, and almost the whole of Caithness, where the belt attains its greatest wiclth.

The ferruginous character of the rocks, and of 
the dry burns on the right bank of that part of the Spey where we have now arrived, attest the presence of the old red sandstone. Geologists tell us that although the bills of this formation are less bold and precipitous than those in primitive districts, yet that they present great diversity of scenery, "here rising in rounded leights, there sinking in easy undulations, now swelling in sunny slopes, and anon retiring in winding glens, or rounded valley-basins of great beauty and fertility." The accuracy of this description is fully corroborated by the character and general aspect of the country through which the river here pursues its course. For some miles the right bank is bounded by a succession of pine-covered hills that stretch far away into the interior, occasionally presenting a steep declivity, supporting on its side numerous quaint-looking pimnacles of conglomerate, that seem almost ready to topple orer and fall into many a dark pool helow, where the rod-fisher can with difficulty obtain a footing on the narrow ledge, and must be master of "the Spey throw" to ensure sucessful sport-there clothed down to the very edge of the shingle with lareh and spruce firs, in a cradual slope, and, still further on, showing the deep gorge of a now dry burn of considerable wilth, extending far back into the evergreen 
woods, and mounting higher and higher in such numerous and eccentric ramificatious, that the eje would occasionally fail to detect their course, but for the zig-zag red lines that pecp out every now and then, and the remarkable arenaceous cones of the same colour, which contrast beautifully with the dark verdure of the forest.*

This may give you a faint idea of the scenery at the mouth of the gorge known as "Alt Derg," or" the red burn, about three miles above Gordon Castle, on the right bank of the Spey, immediately opposite to what used to be one of the best salmon pools in the river, but although those which oceur "above bridge" + are not subject to such complete annual metamorphosis or total destruction, as affect almost all the others below it-and through the whole extent of three or four miles which may be said to comprise the delta of the spey-yet such is the tremendous power of the winter floods, that the depth of the water and the chiracter of the stream is liable to constunt chnnge, eren liere; pools being occasionally filled up with shingle, rocks, gravel, and débris of all kinds, and a considerable extent of the mendows and cultivated

* Realers who take an interest in the seenery of Scotland, viewed in connection with ity pliysical geology, should consult the charming volume of Professor Arelibald (keikie on this sulject.

t The great bridge crossing the sley near Fochabers. 
fields on the left bank carried away, in spite of the persevering efforts of the landed proprietors to neutralize the effects of the flood, or to repair the damage by buttresses of timber enclosing hugre masses of elosely packed boulders, chevaux-de-frise of fir-trees, and similar contrivances to resist the torrent.

I have just said that the salmon pools between "Boat o' Brig" and the Spey bridge-which spans the river near Fochabers-preserve, less or more, their locality from year to year, although their depth and character are frequently altered; lut the case is very different "below bridge." 'J'here are occasional exceptions to this-but they only serve to prove the rule. A more particular description of some of these pools may be attempted hereafter. 'Ihis is only a rough sketch -a bird's-eye view, as it were, of the river and its shores.

For some miles past, the hills on the left bank have retired from the bed of the stream, and the rich allnvial plain is the site of several of the most fertile and highly enltivated farms in the north of Scotlamd. On nearing the bridge the higher ground gradually approaches the river, which here cuts its way for some distance through a rock of red sandstone; but shortly after, the 
eliff, gradually lowering, retires on the left, while on the right the pine-covered hills recede still further from the stream; and now the welltimbered grounds of Gordon Castle open on the view, rising from the intervening plain, until the verdure of the decr-park, varied with heathery moorland, is succeeded by glens of deciduous trees and giant larches, beyond which a wide forest of primeval pines stretches for many miles over the hills, and forms a dark background to the picture, from which the old central tower of the Castle and the spire of Fochabers Kirk stand out in sharp relief.

Still lower down, the gorse-covered wastes and alder woods that flank the low shores, are regularly inundated by the winter floods, which, on retiring, leave numerous clear pools of water. Many of these, shaded from the sun, and protected from the drying winds of spring and summer, are never exhausted during the rest of the year, and become a farourite launt of wild dueks and other water-birds during the later antumual months.

I should have mentioned before this that the fall of the river between the bridge and the sea, a distance of nearly five miles, is considerable; and as no caseade occurs in the interval, the force of 
the eurrent throughout is necessarily very great.* Numerous rapids, as well as deep pools, continually suceeed each other, and the water, even within a liundred yards of the sea, is perfectly fresh at all periods of the tide; while from the frequent shifting of the bed of the stream, this river, although it ranks as the second in Scotland in its rolume, draining not less than 1300 square miles of eountry, is not navigable. Indeed to the realization of such an iden, fresh obstacles, more welcome to the salmon-fisher and the wild-fowl shooter than to the political ceonomist, continually oceur during this portion of its final course.

And now the "haughs," or real winter banks, of the Spey, withdraw gradually on either side; the intervening space, sometimes more than a mile in width, being, in fact, the delta of the river; a veritable wilderness of houlders and shingle, raried with islands and peninsulas, some mere sandhanks, others covered with alders, gorse, and bushes, throngh all of which it meanders in a perfect labyrintly of streams. These oceasionally meet, only to separate again ; and although they

* "It is the most rapid river in Scotland. Its fall for the last three miles of its course is sixty feet." - Survey of the Prorinee of Morm, published at Aberleen,. .1 .1798 , page 99. 
ultimately reunite just before reaching the sea, their tortuous course is sufficient to perplex even the experienced salmon-fisher, whose geographical recollections of the maze of last autumn are completely obliterated by the new ragaries in which the river has indulged during the "spates" of the previous winter. 


\title{
A DISAPPOINTMENT.
}

\author{
. . "Nonne vides \\ Regius ut placida tibi majestate per undas \\ Rarlit iter, liquidoque superbit gurgite Salmo. \\ . adrersum quà spumans ingruit amnis \\ Tollit ovans sese, et multo luctamine victor \\ Exilit."

$$
\begin{aligned}
& \text { James Parka (Lord Wensleydale), } \\
& \text { C'ambridge Trigros lerses, } 1802 .
\end{aligned}
$$

Ir was on a sunny afternoon in September that I started for a part of the river about two miles below Gordon Castle. "A southerly wind and a clondy sky" are not snch necessury conditions of suecess on the Spey as elsewhere, the rupidity of the stream generally ensuring suflicient disturbance on the surfuce of the water, although a dark day is always welcome to the fisherman.

The weather had been dry and sultry for a long time. There were but few henry salmon in uny, even of the best pools, and most of these hat "tasted steel." The river was much lower than usual at this season, and the water transparently 
clear, so that a single-gut casting line and a small fly were indispensable. Day after day we had all been longing for a fall in the barometer, to be followed by a good "spate" * to bring up the large fish from the sea, which were only waiting outside for more water, to enable them to pass the bar, rush up the stream, and reach their farourite pools. The best season for the angler lad but lately commenced on this lower portion of the river. The netting hal ceased since the twenty-sixth of August. Not a single kelt had yet been observed on his or her downward royage, and nothing was wanting but a supply of fresh-run salmon, which were now overdue.

From what I have said of the velocity of the river, and the frequent and shallow rapids occurring between the pools in this portion of its course, you will be prepared to beliere that the fisherman must either throw his fly from the hank or wade into the stream for that purpose, and that a boat of any kind would be troublesome to manage on its surface. Such, indeed, is the rule, which in this instance, as in many others, may be proved by a solitary exception. A small coble

- Sprate-spait-sporat, a flood.

(Haclic, speid-perhajs from spe, froth.-Jayresos's Dictionary of the Seottish Language. 
can generally be seen, during the early morning, drawn up high and dry on the shingly beach near the bridge pool. This luxury, however, is reserred almost exclusively for the ladies, and as it draws very little water, can be narigated by the skilful boatman who always accompanies themhimself one of the best fishermen on the Speyin perfect safety over all the rapids as far as the sea; but its return journey next morning is necessarily ly road. A liorse and eart, especially adapted for the purpose, meet it at the Tugnet, and conrey it back to its usual station near the bridge. Sometimes a similar expedition takes place up the river, when "the overland route" being first accomplished, the fair anglers descend the stream from Boat o' Brig, passing the beautiful seenery on the right bank, which I have already described, and trying their fortune in the Couperee, the Chapel pool, the Rock pool, or the Greenbank, on the downward royage, and seldom without considerable suecess.

You will conclude therefore, and truly, that, like $\mathrm{my}$ friend the heron, I am a wader; and indeed, without any desire to depreeinte the adrantages attending the use of a boat on certain rivers, or denying its absolnte neeessity on others, such as the Tay and the Tweed, yet every expe- 
rienced salmon-fisher will eoineide in my opinion that in a rapid stream, with well-defined pools, it is better to dispense with its services, and that an indescribable eharm is added to the sport by abstaining from any further aid than is afforded by a perfect Macintosh equipment, and the attendance of a clever clipper.

Apropos to this subject, I must tell you something of the individual who now accompanied me in that capacity. My first experience of lim was at the commencement of the previous season. He was then a little boy about twelve years of age, and hardly strong enough, or tall enough, as I fancied, to gaff a large salmon, or wade after me into deep water, as would occasionally be necessary. But there was something very promising about him. He was remarkably quiet and taciturn, and although at first a little awkward, yet, before a month had elnpsed, I found that, from his natural intelligence, his lowe of the sport, and his amphibions habits, he possessed, in embryo, all the qualifications of a perfect aquatic gillie. He soon beeame an adept with the clip, seldom missing when le had a fair chance, and rarely throwing one away; while to his coolness and presence of mind in moments of difliculty, during a long and exciting run, I have since frequently 
been indebted for the successful capture of many a heavy fish.

This was the beginning of Simon's second season as my attendant, and as he had been down this part of the river before, during the net-fishing in the summer, I questioned him as to my prospects of sport.

"Deed, sir, I canna say : I'm thinkin' there's a wee bit too mueh sun the day."

"But how about the new pools? I see that the river has not only struek out fresh channels for herself since last yenr, but that, if I am not much mistalien, the valley of boulders, that we are now actually trudging over, must be the dry bed of what used to be one of the best easts in the river, where I killed the thirty-two pounder."

"Aye, is it, sir, the varra spot."

"But how many pools are there?"

"Well, I cama say-not many, that will hold a muckle fish, until we get a good bit lower down."

We had now walked over a considerable extent of boulders and slingle, and reached the nearest arm of the river, which appeared too shallow eren for a grilse, so wading though it, and agrain traversing another peninsula like the last, and crossing a second branch, which looked cncourng- 
ing, about a hundred yards lower down, I commenced operations there at once in a narrow but deep and turbulent pool, at the lower end of which I could just see the upper portion of a rapid, where the stream became wider and shallower, as it suddenly turned to the left and was then lost to riew.

My first two throws were just abore the boiling water through which the fly-a small black king -was whirled about in all directions. At the third, with a longer line, it dropped almost at the margin of the opposite bank, passed quickly through the whirlpool, and swam steadily through the strong current a few yards lower down. While my eye was fixed upon its morements, a sudden splash, close to the spot, gave the first promise of sport that lad greeted me for many days. Only a rise it is true, but a real one. Half a dozen steps backwards, a few throws higher up, and the fly was over lim. Another splash, but $n$ lo lold of him yet. Once more I retired six paces, and now with increased excitement repeated the sume process. A sudden plunge and a chuck told that I hand got him this time.* First, he rushed up, the stream, the line

* Notwithstanding the thrill of delight that electrifies every fisherman at the moment when he hooks a big salmon-espeeially 
hissing through the water-then he sprang into the air again and again, a splendid male fish-a twenty-pounder at least, fresh from the sea, as bright as silver, and with a distinct semicircular seal-bite on his side, just auderneath the dorsal fin. This I noticed several times. Well, I managed to keep above him, and played him up and down the pool for nearly a quarter of an hour, Simon in the meantime creeping eautionsly along the edge, gaff in hand, and eagerly watching for an opportunity to perform his part in the ceremony. At last I tried to coax the fish within his reach, but he was still too lively, and the water too deep just under the bank, for the boy to elip him there, so, after a few ineffectual attempts, I turned his head down stream. This proceeding would, of course, hatve soon reduced him to

if he has previonsly raised hin unsuceessfully two or three times -yet 1 never could share the feelings of some anglers of my aequantance who aver that they would then willingly hand over the rol to at less fastilious sportsman, and that the sulsequent contest, and evon the landing of your fish, are combaratively uninteresting. Sueh a proceding alpears to me to be jrecisely analogous to the conduct of a master of hounds, who, while bunting his ow unack, would, immediatedy after finding his first fox, call then off in quest of a secombl, thus completely ignoring the pletsures of the chase, the glorious exeitenent of the first lurst, and all those "moving accidents ly thood and field" that coustitute the great charm of fox-hunting, and in which the true salmon-fisher equally participates. 
obedience if it could have been continued long enongh, but we were now quickly appronching the lower rapid, and, as the force of the current gradually increased, the partially subdued fish resigned himself totally to its influence, the line ran out faster and faster, and my hope now was that by exereising as much gentle restraint as was possible under the circumstances, I might check his downward eareer sufficiently to enable Simon-who was already up to his knees in the midkle of the shallow-to gaff lim as he was pussing. Down went the fish at a tremendous pace, floumdering and wriggling over the stones like a gigantic eel, with lis dorsal fin ont of water. "Now, Simon, you have him !" I cried, as I saw the boy make a lunge with the clip ; but the whizzing line told me too truly that the stroke had been unsuecessful, and the pree was too grent to artmit of its being repeated; so rushing ulong the bunk and winding up whenever I had a chauce, closely followed by Simon, I felt nt that moment, as certrin of ultimate success as a sulmon-fisher can feel under any eircumstanees, for I knew that the hook, although a small one, must havo a fair hold, and the single gut hat aliendy stood a severe test. The tril of the rupid was now within sight, and I anticipated no difficulty in 
bringing matters to a conclusion in the nearest pool below, when suddenly-just as my hopes were highest-I perceived, to my horror, another deep stream in front, rumning in from the left, and realized the unwelcome fact that $I$ was on a peninsula, below and around which all was dark and turbulent from the meeting of the waters. What was to be done? The line was quickly running out. It was too late to retrace my steps, and though an expert swimmer under ordinary circumstances, I had previously experienced the danger of venturing out of one's deptls in long, leary, wading hoots, such as I was wearing at tlat moment. My first impulse was to pull them off, and, rod in hand, to tread water down stream, landing on either hank, below the junction of the two arms of the rirer, but there was no time to carry ont such an operation, even with Simon's assistance. The line was whizzing away, and a glance at the deep stream on the left-now ratlier above me, for I had waded out on the tongue of the promontory until the water had filled my boots and was up to my waist-revealed no hope in that direction. In agony I looked at the now emptying reel. But a few yards remained: these soon disappeared; the strain grew greater and greater: something must give way; the rod 
bent more and more, and then suddenly became - perfectly straight! I will not dwell on the misery of that moment. Frequently as they occur in the experience of a salmon-fisher, yet the bitterness of such mishaps nerer seems to be mitigated by repetition. 


\title{
INCIDENT DURING A ROEDEER DRIVE.
}

\author{
"Oft expectation fails, and most oft there \\ Where most it promises, and oft it hits \\ Where hope is coldest and despair most sits." \\ All's Well that Ends Well.
}

For some days afterwards, the weather continued sultry and unfarourable for fishing. The blue slif, unbroken by a single clond, was as unpromising as ever, and it was, therefore, with no little pleasure I leamed, one afternoon, that a roedeer drive in the great fir-woods had been arranged to take place on the following day.

It happened that my bedroom window commanded a view of a portion of these hills, and, as I drew up the blind on that morning, the scene, lorely as it always was, certainly secmed to possess eharms for me that I had never felt hefore.

To the south, and immediately beneath me, were the benutiful gardens and pleasure-rrounds, laid out in the Italian style, gorgeous with 
flowers of every imaginable colour and variety, in the midst of which magnificent fountains threw their lofty jets of the clearest water high into air, or poured it, in mimic caseades, into wide basins below; while the lines of balustrade that separated this fairy land from the park on either side, were broken at intervals by urns of various sizes and forms, and statues of stags, or gigantic dogs, standing off in relief from the dense foliage of the lime-trees. Bounding the view in this direction, and contrasting powerfully with the Southem character of this home scene, rose the pine-covered hills, nearly two miles off, which were to be the scene of our sport in a few hours; while a narrow cutting, exposing the tall stems, could be seen ascending from the base of the rising ground, like a elearingr in an American forest. These fir-woods extended for miles firr away towards the east, and round to the northeast, the "saw-edge" profile of their outline being backed by the sky, or, occasionally, by the heathery heights of more distant moorland.

When assembled at the appointed hour, we numbered about eight grms, and proceeded to the rendezvous on the outskirts of the wood. Here were already collected several keepers, clad in shooting dresses of Gordon tartan, and numerous 
beaters to assist in driving. Operations commenced by our forming a line, about a quarter of a mile long, the shooters being placed as nearly as possible equidistant from each other ; and thus, with an extended front, we marched abreast about a hundred yards up-hill, then wheeling to the left, by word of command passed along from the pivot flank, we drove the pine-forest diagonally, over great variety of ground, now up to our knees in heatler, and now deseending the steep and rugged slope of a lry red sandstone watercourse, or scrambling up the opposite bank, and endeavouring all the time to preserve our line as nearly as possible-a difficult task while out of sight of each other, or only eatching an oecasional glimpse of the nearest beater on either side. Every now and then a distant shot, or two or three in suecession, would tell that a buck had been killed, or was rumning the gauntlet, or perhaps that a blackeock had been sprung by the beaters. As yet I had seen nothing in the way of game, exeept a few hares, and having no intention of throwing away my ammunition on them, my gun remained still undischarged-one barrel loaded with buckshot, the other with No. 5 -and I was just beginning to grumble at $m y$ bad luck, when we emerged all at once from the 
tall pines, and came upon a wide extent of open moorland, studded with clumps and irregular patches of spruce and Scotch firs, of younger growth. Here an opportunity of "dressing up," in military parlance, was afforded to as many of us as were within sight of each other, although at least three-fomrths of the field were out of view on either side. Finding myself considerably in the rear, I was running forward to the front, and had hardly plunged into one of the clumps that interrened, when a cry of "Roe! roe!" followed by a report from the right, reached my ears. Hurrying through the trees, I was just in time, as I emerged on the opposite side, to eateh a glimpse of a fine buck, passing at full speed about thirty yards off. My first shot, directly in front of his shoulder, was unsuccessful; with the second he rolled over, and the next moment the hunting-knife of the nenrest keeper finished his carcer; but I found that, notwithstanding my previous conviction of the impossibility of such a blunder, I had thoughtlessly discharged the barrel containing small shot first, which, at that distance, is rarely sufficient to loring a roedeer to the ground.

We were now among the linunts of the black game, and several noble male birds of that species 
fell at intervals along the line, soon after which we converged upon our eentre, and a halt was called. Some time elapsed, however, before all the stragglers, shooters as well as beaters, were collected together. Now and then, a keeper might be seen, slowly crawhing through the heather, with a buck or a doe slung over lis shonlders, while another would appear from the opposite quarter, with feathered game or hares in either hand, until at last all were assembled, and the varying fortumes of each sportsman hurriedly related during the brief time allotted for luneheon.

And now the "drite" was about to assume a totally different character. As yet, we had been unassisted by any dogs, except a few sedate retrievers, who walked listlessly lehind their masters, and preserved their grave demeanour, unless, when occasionally put on the track of a wounded roe or a winged blackeock, when their services proved invaluable; but now I first obscrved, in charge of a new bateh of keepers, a motley pack of dogs, of various sizes and breeds, conspicuons among which was a huge black and tan bloodhound, of the true musical, long-eared type-a host in himself, I was assured, and especially adapted to the kind of sport that was now about to commence. 
A short walk from this spot took us to a new portion of the forest, on more elevated ground, where, instead of the lofty primaval pines that clothe the base of the hills, we found ourselves among Scotch firs of lesser stature; their trunks naked for some distance from the ground, above which their horizontal branches grew thiclily in all directions. We were now walking along silently, in single file, when the keeper who was conducting us suddenly stopped, and pointing to a tree at a little distance, directed the shooter who was nearest to him to take up his position among its branches. An ordinary passer by would have seen nothing to attract his attention, but a more careful examination revealed a mass of bourglis, like a huge bird's nest, about twelve or fourteen feet overhead, with a rude and frail ludder of firsticks fastened to the trunk, leading up to it almost perpendicularly, and suergestiug altogrether the idea of a so-called gorilla's dormitory, lut seeming to evince less architectural talent in its construction than that quadrumane would have exhibited. These hiding-places were arrumged in trees about a hundred yards aprart from each other, and in due time I found myself concealed in the particular one allotted to me. 'Then I could perceive that the apparent rudeness of the details was 
intentional- $\mathrm{a}$ fow bark-covered sticks, nailed together, formed the floor, the sides were equally simple, and through these the living boughs were roughly interwoven.

Some time elapsed before all the gumners were located in their respective trees, during which I lıd ample leisure to study my position. I found that it commanded a narrow vista, immediately in front, intersected by a path or favourite run of the roedeer. These tracks were well-known to the keepers, and the trees containing our nests were selected hy them for the sake of any arlvantages of this kind that they seemed to possess. To the right and left the dense foliage shut out the view, but immodiately behind me the ground was comparatively open, and several firs, taller thun the one in which I was concealed, rose out of tho heather, the upper branclues of one of the nearest, loaded with eones, luanging almost over my hear. Through an interval between these loftier trees, I pereeived that I was on the ridge of a lill; for a little lower lown, the summits of the pines alone were visible; and as the ground sloped away in that direction, I could catch a glimpse of the Spey, like a streak of bright silver, and still further off, the blue mountains of the distant Higllands. 
I should have mentioned that, during the time occupied in placing us at our different stations, the hounds had been taken, by a cirenitous route, through the woods to a considerable distance, accompanied by an army of beaters, and as soon as all was ready, the report of a single gun announced the fact to the liuntsman, who, at once, with all his assistants, luman and eanine-the former drawn out in a line-commenced operations. The denseness and great extent of the pine-forest, and the undulating natme of the ground, for a long time prerented my hearing any sounds proceeding from that direction, but presently the distant report of a gun, quickly followed by another, told me that a roe was alreaty on the move, and that some fortunate sportsman had not been long liept in suspense. The day, like so many that had preceded it of late, was close and sultry, and the persecution that I endured from gnats and midges far beyond anything of the lind I had previonsly experienced. 'Their attacks, indeed, ats I found on many snbsequent occasions, constitute the stamdard plange of a roedeer drive in these woods. When seated on the ground, the victim is most severely punished. The retreat among the boughs above furnished somewhat of a sanctuary, but eren here 
it is bad enough. Smoking seems to afford a temporary relief, and to repel the enemy for a time, but no sooner is the pipe empty, or the eigar finished, than these Lilliputian tormentors recommence their attacks, and give even the untravelled sportsman a fair idea of the powers of the musquito in India, or of the swarms of gnats in Norway and Lapland.

I had just finished my fourth pipe, when the distant sounds of dogs and men fell on my ears. The chasse was evidently approaching. A shot soon followed from the same quarter, the yells and shonts becume louder, and the ery of the hounds more distinct. l're-eminent above all was the deep baying of the bloodlhound, who was appatrently following a line of his own, and gradually, but pereptibly, nearing my position. Now it ceased altogether, then suddenly recommeneed within a hundred yards of me. It was an exciting moment as I linelt down in the nest, and, with my finger on the trigger, fixed my eyes on the spot where the deer-path crossed the nurrow vista in front of me. Presently the loud and continuous notes of the bloodhound told that he was close on his quarry, and I felt sure that he was driving it towards me; then followed a rush and a crackling of the rotten sticks, elose by, but 
instead of a goodly buck, as I had fondly expected, out bounded a poor little fawn, and stopped for a few seconds in the opening, trembling and looking about, as if not knowing in what direction to fly from its persecutor. There it stood, within twelve yards of me, an easy victim, but I could not find it in my heart to pull the trigger. On it passed, the hound soon crossing at the same spot, and pertinaciously sticking to the seent, although no match in pace for the animal he was pursuing. Long and anxiously did I listen, until his deep notes gradually died away in the distance, and as no shot was fired afterwards in that direction, I concluded that the poor thing had run the gauntlet in safety, and congratulated myself sincerely on having abstained from thoughtlessly putting an end to its existenee.

For full an hour afterwards dicl I keep watch, staring at the opposite path, at first anxiously, then listlessly, in the vain hope of seeing a buck pass, althongh roused every now and then as the shouts of the drivers occasionally reached my cars, or the tongning of a hound, gradually approaching lont finally passing unseen, like the animal he was chasing, ruised my expectations to the utmost for a few moments. At last, becoming resigned to my bad luck, I turned round in my 
phace of eoncealment and again admired the glimpse of the distant landseape between the taller trees in the opposite direction. Nothing lind struck me more throughout the day than the perfect stillness of nature, the uninterrupted silence reigning in these fir-woods. With the exception of the solitary fawn, I had neither seen nor heard any native animal sinee I ascended to my place of coneealment. I was especially surprised at the total absence of all kinds of small birds, some of which, such as the great tit, the blue tit, or their congenors, the marsh or the eole tit. I should have expected to see or hear even at this scason. or at least to have eamglit a glimpse of some feathered inhalitants of the forest. This cirenmstance had just recurred to my memory with redoubled force, as I perecived, by the deelning sun, that the evening was approaching, when sudienly a singular, continuous, shrill ehirping sound reached my ears, as of several small birds together, but the notes were strange to me. Although well acquainted with the call of most British birds. I could not recognize this one, and the longer I listened the more I was prazled. Gradually it approached, and seemed to proceed from one of the taller Seoteh firs at a little distance. Fixing $\mathrm{my}$ eyes on the spot, I 
soon saw several little hirds, something larger than bullfinches, emerging from the foliage, and, flying one by one towards the tree that was nearest to me, alight on the very boughs that hung over my head. I could hardly believe my eyes, as I realized the delightful fact that I was actually within a few yards of a whole family of crossbills, loxia curvirostra, busily engaged at their marvellous employment of splitting the fir-cones and extracting the seeds.

Need I say that the recollection of previons bad luck, and even my sufferings from the gnats, were olliterated by such an interesting sight, not the less welcome from its being so unexpected. 'The very plumage of these little creatures added to the charm of their presence. Some were of a benutiful deep erimson colour, others orange ol yellow; others, again, were elad in a plain brown livery, and all were busily intent on their ocenpation of rifling the cones, during which they kept flying about from one twig to another, incessantly uttering their shrill, monotonous notes. After close observation, I noticed that they scliom attempted to operate upon a cone on the exact spot where it grew, lut after snapping one off from a slender terminal twig, encl lird would hop or fly to the central part of the branch, and in parrot-like 
fashion hold it in his foot, but more frequently under it, as a hawk holds a small bird when in the act of devouring it, and quickly inserting his lill between the scales, split them open by means of that wonderful tool, and extract the seeds with the greatest facility. Occasionally a cone would fall to the ground just as it was snapped off; but, in such a case, a fresh one was instantly selected, no further notice being taken of the one that had dropped. Their powers of climbing appeared fully equal to that of the titmice, as they swmorg ahont in all directions and in every imaginalle attitude, twisting and twirling, fluttering and chattering, within a few yards of me, and evidently quite unconscions of my presence. This was too good to last. The lond eries of the beaters, now rapidly approaching, had for some time overpowered the notes of the crosshills, and amounced that the classe was drawing to a close. Fither alarmed at this, or having completed their selection of the most tempting cones in the firtree over my head, some of the little birds were evidently preparing for a move, when suddenly a rushing sound behind me recalled me to eomsciousness, and turning about, I had just time to catch a glimpse of a fine rochuck, with a capital head, dash across the rista within twelve rards of

D 2 
my position. My gun, on half-cock, had long reposed in the hollow of my arm, and there it still remained, as useless, under the cireumstances, as a walking-stick. I will not venture to assert that I felt no mortification at that moment, nor when relating the incident to some of $\mathrm{my}$ more successful brother sportsmen afterwards, but I can sincerely say that the disappointment was more than compensated by the rich ornithological treat I had the good fortune to enjoy. 


\section{A FRIEND IN NEED.}

" IIe flies aloft an! flounees round the pool, Indignant of the guile. With yielding hand That feels him still, yet to lis furious course (iives way, you, now retiring, following now Aeross the strean, exhaust lis idle rage."

Thomsos's Seasons.

Anoct a week had elapsed sinee my last visit to the lower part of the river, when a sudden fall in the barometer promised a change for the better. This expectation was encouraged by the fuct that the wind had veered round to the north, the wet point in this part of Scotland, where the German Ocean performs the same duty as the Atlantic in the western and sonth-western portions of the island. Our hopes of a spate, however, were disappointed. The rain, it is true, fell over the Moray Firth and the adjacent districts, but seemed to have exhansted its treasures before reaching the Highlands to the south, where the lesser tributaries of the spey, of late nerly dried up, derive their sources, and materially affect the state of the water. 
Nevertheless, although perfectly transparent, it appeared to have risen a few inches, quite sufficient, under the circumstances, to encourage the hopes of an ardent salmon-fisher; and it was with a secret feeling of satisfaction that I now found myself "told off" to the very part of the river that had been the scene of my previous disappointment.

On this occasion I was accompanich by a young friend, whom I shall call $A$, and the boy Simon, who was to perform the duties of clipper for both of us; and, as we were likely to be employed in different pools during the day, we provided ourselves with shrill whistles, by the use of which we could summon him to our assistance as we might respectively require his services; the human voice being more easily drowned in the noise of the rapids.

I have already said that as the Spey approaches the sea, it, or "she" - as the river is always designated here-divides into several brunches. Some of these, after ruming for half a mile or more, again join the main current. 'Thus-as I had now grood reason to remember-one may find one's self occasionally on the point of a peninsula, with a stream roaring on both sides. If too deep to cross in wading boots, and with a big 
fish at the end of one's line rushing down, he is as good as lost. But I had now gnurded arainst the probability of such an aecident by substituting my long Macintosh overalls, reaching upwards as high as the chest, supported over the shoulders by short braces, and tightly fastened round the waist by a hempen* cord to prevent the ingress of water to the lower regious; while thick, short, worsted socks, and large, well-nailed brogrues, buekled over them, completed my equipment.

Frequently since lust week lad I thonght over my late mishap, und mentally recapitulated every incident that had occurred, and as often derived consolation from the conviction, that, unless I could have crossed the upper part of the rapid, where simon had failed in his attempt to clip the salmon, or over the stream that cut me off on the left, I could not have prevented the catastrophe. All this was passing through my mind for the hundredth time, as, after separating from $1,-$ whom I left with simon at a pool on the right bank of the main current,-I waded over to the opposite side, a little ubove the seene of my former

- I have found this better than a leather strap, as it tightens when wet, whereas the latter becomes relaxed if saturated with water. 
adventure, impelled by an uncontrollable desire to try the same spot again. Not that much had as yet occurred to excite my hopes. We had agreed to use different flies, and neither my companion nor I had as yet raised a single salmon, although we had tried sereral kinds in succession, and in likely places. I was just beginning to think that the river had not risen sufficiently to bring ul any fresh fish from the sea, or even to indnce the fow she already contained to change their quarters, when I found myself close to the top of a rapid, and immediately below it a boiling pool, which I at once recognized as the identical plice where I had hooked my rmnaway last week, and as I looked at the spot I could not help feeling the disappointment keenly renewed. The sun was now low in the horizon, and putting on a brighter fly, but with little hope of a rise-indecd almost mechanieally-I threw into the torrent, and when the line was straiglit worked it out into the decp water at the side. Splash! A rise, but fortunately no touch on the liook. How my lienrt. beat! for I knew by the vigum of the plunge that it was a large salmon. However, I did not forget to repeat the prulent tacties of an old fisherman on this occasion, and walking hack six paces, I slowly retraced them as before, with a throw at 
each step-taking especial eare to preserve the same length of line. Just as I took the sixth and last, and as the fly touched the water, another plunge, and a simultaneous turn of the wrist on my part was followed by a ehuek; then fiz-fizand away went the fish down stream, making straight for the dreadful rapid below. Suddenly he turned right abont faee, and I had hardly time to wind up the slack line when he sprang high out of the water, revealing to my astonished sight the identical hero of my former adventure. There wns no mistaking him. Short and thick, in proportion to lis length, with his blue back and silvery sides, and the same erescent-shaped seallite just helow the dorsal fin. But the odds were all aguinst his speedy eapture. I whistled, and whistled, and even shouted, in vain, to attract the attention of Simon or of $A$. The roar of the torrent drowned every other sound. At last the boy canglit a ylimpse of my rod, bent like a bow, aud as I threw a hurried grance up the river, I saw my friend, who had been trying the pool just alove, fling down his own rod, and snatehing the gaff from the reluctint Simon, run to my assistance at his best speed, but still at the opposite sitle of the stream, and lower down than where I had crossed. Here he at once com- 
menced wading, but the passage was necessarily a tedious task, the increased force of the current at this spot rendering great care necessary, while the splendid fish, all this time, kept rushing about and leaping high out of the water, evidently, as I believe, trying to fall on the casting-line momentarily rendered slack by his somersaults, but fortunately he did not succeed in this manœurre, and then taking to sulking, down he went to the bottom.

We had now time to loold a council of war, and we arranged that if the salmon should ultimately repeat his former tacties, I should try to coax him over the shallowest part of the rapid in his descent, while $A$, having taken up his position there beforehand in the water, would look out for his back fin and endearour to gaff him as he passed-the very operation in which Simon had previonsly failed. In the event of this not succeeding, I made up my mind to wade across to the opposite side of the river, taking care to have as little line as possible out at the time: thus I should not be stopped by the deep stream lower down on the left, which hud ent me off on the former occasion. However, the first step was to rouse the fish ont of his sulky fit. Here great delicacy combined with firmuess was of impor- 
tance, for the water was exceedingly trausparent, and, together with the brightness of the weather, and the slynness of salmon at present, necessitated the use of very small flies and single gut castinglines. Anything, therefore, like violence in dealing with a large fish must have been followed by its instantaneous loss. The first point, then, was to compel him to move, while I kept up a steady and regular pressure on as short and perpendicular a line as possible. A therefore waded in and threw a large stone just above him; then a second, and a third. Away he went again, and as I succeeded in coaxing lim at last into a little bay of dead water, I was in great hopes that we should have gafied him there; but he got a sight of the clip, and darted off once more into the middle of the cmrent: howerer, he was now too weak to work upwards, or eren to resist its force, so turning his head down stream, he dashed resolutely at the rupid, repeating, as nearly as possible, his previous performance. This was the crisis. A got to the middle of the water, while I took a hasty survey of the place where I must wade or swim over if lie missed the elip. All this occurred in a few. seconds. Down went the fish over the shallows, his back fin and the upper part of his tail appenring above the surface; but the pace was tremen- 
dous, and I dared not attempt to check it by an increased pressure on the line. At this moment, just as he was approaching his fate, he rushed into a deeper part of the rapid, A resolutely plunging after him, and almost inserting the elip); but the force of the current, and the sudden exertion combined, carried my friend of his legs, and in an instant his long Macintosh stockings filled with water, and he was swept down some distance, but fortunately recovered his footing, and getting safely back to shore, prepared, if neecssary, to swim over to my assistance after I had erossed. As for myself, the moment I saw that the fish had eseaped, and was earried down the rapid towards the deep water, I waded over to the opposite side, aceording to our previous arrangement. It was just as much as I could do withont swimming. The round houlders at the hottom, already pressed upon by the foree of the stream, seemed to fly from under my feet, buoyed up as I was by the air confined in the legs of the overalls. As I got elose to the land, the water was up to my armpits, and $I$ land a strugrgle to elimb the hank and to keep the rod upright all the time, while the line was whizzing away, and it secmed donbtful, for a fow moments, whether the recl would not be emptied before I obtained a footing on terra firma, 
and the misfortune of last week be repeated. Once there, however, I felt almost sure of ultimate success; and I saw A-who, by the way, is a eapital swimmer-plunging in from the opposite shore, having got rid of his Macintosh stockings, and coming to my assistance, and by the time he was over I had run down stream and wound up at least three-fourths of a humdred yards of line. From this spot, almost as far as the sca, the river pursues her tortuous course, more intricately tham ever, in a succession of rapids and small pools. Here and there, near the upper part of the former, it was easy to cross by waling, and once more passing over to a long streteh of shingle, at the other side, I managed to lead my fish, now nearly tired out, down stream for a considernble distance, without meeting any formirlable obstacle. His dying strugroles cluring the latter part of the run Ind evidently uttucted the attention of a great black-backed grull, who, aceompanied by severul immature birds of the sume species, continued to som over our hends, every now and then darting down elose to the salmon as he turned over helplessly, and his bright silvery sides gleamed through the water; doubtless watching, with the true scarenger instinet, for the moment of dissolution, though apparently uncouscious of the eause of his 
difficulties, and quite ignoring the presence of his persecutors. Now, at last, I was preparing to pilot him into a promising little haven of backwater lower down, which was soon reached, but the great force of the current earried him past, in spite of all my manœurring. That was a eritical moment. If the hold of the hook had been less firm, or the gut any but the very best, I must have lost him, for I suddenly saw, to my dismny, that we were again on the extremity of another promontory, a second wide stream rumning in a little below us, and the dark water showing everywhere the increasing depth of the river. Now or never! I put on a strong but steady pressure; gradually the half-exhansted fish yielded so far as to roll heavily towards the side. His back fin is at last visible, now his hroad fun-like tail appenrs for a moment. In dashes $A$, and in the rery nick of time, just as we arrire at the junction of the two eurrents, makes a bold stroke with the clip. Bravo! the prize is ours, and I am on the point of lowering the rod, when, to my horror, I see the gaff break off short in the hand of my friend. Our fate hangs on a hair. T'he next moment I lose sight of all except his head, but in an instant afterwards he reappears, clasping with both arms a goodly salmon-twenty-two pounds' weight-as 


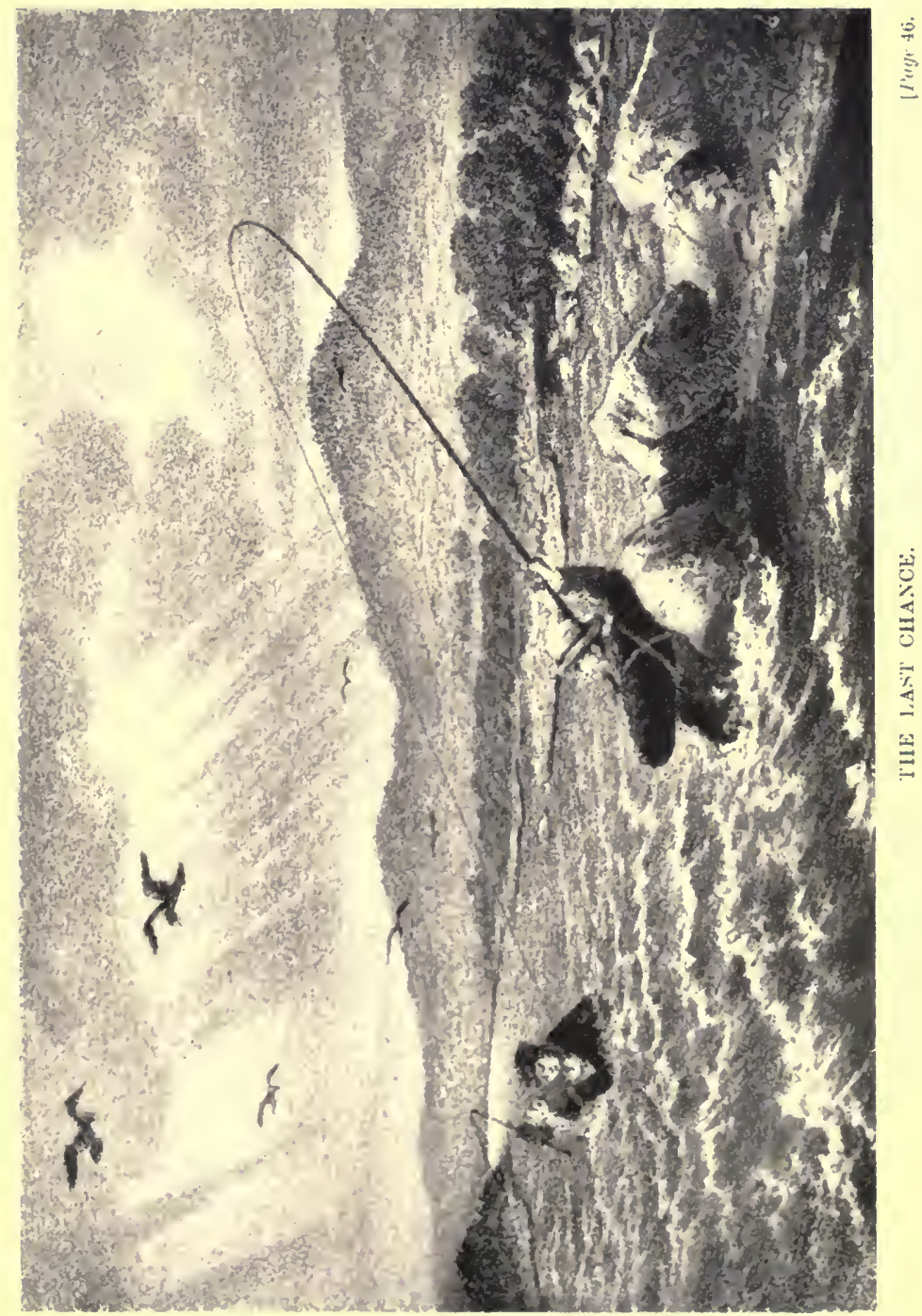



it struggles rainly to escape from his fond but firm embrace. It was indeed "the last chance," and I could not help feeling that the successful termination of the adventure was due to the assistance of my friend, or, to say the least, that " the houours were diviled;" and I never more sincerely acknowledged the truth of the old familiar aduge,

" $\mathrm{A}$ friend in need is a friend indeed." 


\section{FERE NATURE.}

"The numerous forests and schases are very profitahle for fuiding of bestial and delectable for houting. They are full of reik deer and roes, woulfs, foxes, wyldeatts, lrocks, skuyrells, whittrets, weasels, otters, martrixes, hiares and fumarts." - Sin Robvit Gondos's Mistory of the Earldom of Suthcrland, A.1). 1 (630.

Althovgin nearly two hundred and fifty years have elapsed since the above passage wus witten, yet all the wild animals here enmerated-with the exception of the wolf*-are still to be met with in the North of Seotland, to the antire of which region we camnot donth that these remarlis were applicalle, although a very perepptible local increase in certain species, mol considerable dinnimtion in otluers, lave taken place chring the last twenty or thinty years.

While inrestigatingr this sulject a few years agro,

- "In Irelind, a species of wolf continned 10 axist until the gear 1710. In Scotland, to the year $16 \times 11$. In Englund, it was extirpated at a much earlier periud." -Owex's Brilish Fossil Mammals. 
in reference to the neighbourhood of Gorlon Castle, I was much surprised, and not less interested, to find that the squirrel, Sciurus rulyaris, by no means rare and still gradually increasing, had been totally unknown even to young men in the days of their borkood. In the highlinds of Banffshire, indeed, many shepherds and foresters with whom I conversed had never seen the animal at all, even in the wooded glens and corries-a fumilia description of its characteristic form, actions, and habits failing to enable then to ilentify it -and on pursuing ny inquiries still further in the lower distriets, where it is now of common occurence, I fomd the popular lielief miversal that it was unknown in Morayshire and Banffshire until a few years uno, when " the Pilyrim Fathers " of the race were supposed to lave erossed the Caledonian Canal from Invernesshire, and that even these, like the lorids of the creation, were desecended from a single pair, which were introdured a few years bofore by a benevolent lady, who, having frequently admired their lively habits and spriglitly attitudes during her risits to Englaud, crented a Girden of Eden for them within the sacred precinets of her purk. Not long afterwards I luat the opportunity of beconing nequatinterl with that aecomplished naturalist, the Rer. Dr. Gurdon 
of Birnie, near Elgin, and learned from him that the prevalent faith in the above story was founded on fact, in corroboration of which, after renewing his inquiries, he has lately communicated to me the following particulars:-

"Squirrels, which now abound on hoth sides of the Moray Firth, were introduced into this district of Scotland in 1844, when Lady Lovat turned ont a few at Beaufort Castle, west of Inverness. They appeared at Kilrarock in 1851, at Cawdor in 1855, and had spreal so far into Elginshire in 1860 as to have been observed at Birchfich in the glen of Rothes. They crossed the Spey a few years ago, and are now to he met with on the banks of the Doveran in Banftshire, while on the northern shores of the Moray Firtl they made a like progress from the Beaufort woods, and were observed in 1858 at Kilmuir Castle.

"At Cawdor, Altyre, and elsewhere, they lave multiplied to a great extent, and have become very injurious to the Scoteh fir and lareh, though chicfly to the former. They are fond of the cones, or rather the seeds, of the spruce fir, lut have not been known to touch its hark as they do-most destruetively-that of the Scotch fir and lareh.

"It is certuinly remurkable that these mimals should have disappeared for so long from a distriet 
DESTRLCTION OF SQUIRRELS AT CAWDOR. 51

where there must always have been sufficient wood to shelter them, and where, of late years, they have been spreading so vigorously and extensively.

"In order to diminish their numbers, and thus in some measure save the plantations from their attacks, premiums have been offered. Mr. Stables, Lord Cawdor's agent, in kindly furmishing me with the following memorandum of the squirrels killed on the Cawdor property, tells me that it is only by shooting that their numbers can be reduced. I terrier dog is very useful, us it runs the scent to the tree they have grone up, and barks very keenly, giving notice to the man in senreh of thems.

Note of the number of squirrels killed on the Cawdor plantations :-

$$
\begin{array}{r}
\text { In } 1 \times 62-469 \\
1563-617 \\
1864-469 \\
1865-609 \\
1566-779
\end{array}
$$

$$
\begin{aligned}
& \text { "In 1567-1164 } \\
& \text { 1869-1095 } \\
& 1869 \text { - } 503 \\
& 1570-56 \pi \text {. }
\end{aligned}
$$

"Mr. Strables remarks that the number killed each year depended a grood deal on the qualifications of the men employed, and on the price paid for each tail. He also relates the following aneclote :-

" Soon after the squirrels made their first

$$
\text { E } 2
$$


appearance in Nairnshire, I recollect crossing the hill between the glen of Holme and the Streens, on the Findhorn. While on the top of the bare hill, one of the men who were aceompanying me, but a little distance from me at the time, was startled by his sheep-dog becoming rery excited, and barking at "a queer wee beastie" among the heather. The beastie, to aroid its persecutor, and seeing no other place of refuge in that treeless region, at once made for the man himself, and at one bound gained the crown of his honmet, to the poor fellow's sad discomfiture, for he deemed himself assailed by something that was, at least, "uncannie.", Mr. Stables adds, "The fact of a squirrel being thus found on a bare elevater moor, at least a couple of miles from the nearest wool or tree, shows that it was in the act of migration.'",

Later in the autumn of the same rear in which I first heard this singular story of the reappearance of the syuirel in the North of Scotland. I was staving on a risit at The Hirsel in Berwickshire, near Coldstream, and on mentioning it to Lord Iome, he was much struck by the account, and assured me that the restoration of the same species to the Sonth of Sentland had been brought about in a manner precisely similar, 
though at an earlier period. The coincidence is certainly remarkable. Squirrels were unknown there seventy years ago, but about that time his lordship's grandmother, Elizabeth, Duchess of Buccleuch, turned out a few at Dalkeith. Before long they increased rapidly, and several were observed at Arniston, twelve miles off. From thenee they spread into Selkirkshire, but, from some cause not ascertained, their further progress seemed to be arrested for a time, until about 1841, when the first squirrel made its appearance at 'The Hirsel, to the great astonishment of the people in the neighbourhood, who hat never seen one before. In this district, though now generally distributed, they are compratively harmless, and escape persecution; their farourite food consisting of the nuts of hazel and beech which, with other deeiduous trees, abound in the adjacent wools and along the banks of the Tweed: but Lord Home says that he has been obliged to reluce their numbers ou his property at Douglas Castle, in Lanarkshire, where their depredations lave caused serious injury to the plantations of lareh and Scotch firs. Alas! it is in vain for even their best friends to pronounce a verdiet of "not gruilty." No one was ever more anxious than myself to credit and, if possible, prove their 
innocence. Nothing short of oeular demonstration could have converted me; and although I have never succeeded in deteeting any external injury inflicted on either spruce or Scotch firs, yet the testimony of Dr. Gordon and others whom I have quoted must be allowed to overrule my negative evidence, while I have been too often an unwilling witness of the havoe they commit among plantations of lareh. The tender bark is a farourite morsel, and exhibits unmistakable excoriations from their teeth, and when the juicy terminal shoot at the top of the tree has just made its appearance, in the warm days of spring, it would, after all, be as reasonable to suppose that a squirrel should resist such a temptation, as to expect a similar aet of self-denial on the part of a London alderman when the young asparagus first comes into season.

The disappearanee of this harly little quarruped for so many years prerious to 1844 , from a distriet where-as Dr. Gorton has observed in reference to Morayshire and Invernesshire"there must always have been a sufficient quantity of wood to shelter them," is certainly "remarkalle," and, in the alsence of my ostensible eause, the field of conjecture is thrown open. In the list of wild animals cunmorated by the old 
historian of Sutherland, which I have prefixed to this elapter, the martrix, or marten, Martes foina, is included. From its arboreal habits, as well as its earnivorons propensities, it appears to me that none would have been so likely to have aeted as a eheek on the inerease of the squirrel, and although the excessive preservation of game and consequent persecution of predatory animals, of late years, in the moors and forests, have greatly redueed the number of martens, eren in their farourite retreats, and actually exterminated them in others where they were once of common ocemrence, yet we know that they abounded in the Hirhlands during the first half of the present century. For example, on the Glengarry property alone, a friend of mine, when lessce, destroyed no less than 246 martens between 1837 and 1840. Now, it is just possible that the excessive prevalence of this species, and the scarcity of the squirrel, may lave been contemporaneousa supposition to which the rapid inerease of the latter in Invernesshire during the last thirty vears would appear to lend some colour.

The "whittret," or stoat, Mustrln erminen. and the weasel, Mustela rulgaris, though less numerous than formerly, are still of ordinary 
occurrence, and figure conspicuously in "the gamekeeper's larder." The "fumart," or polecat, Mustela putorius, is rare, while the "brock," or badger, Meles taxus, and the wild cut, "Felis catus, have retreated to the comparatively inaceessible strongholds of the rocks and mountains. Indeed the latter animal has become exceedingly searce. I never met with one in the wild state, and the only living example I have seen in Scotland was at Balmachan, confined in a large iron cage-a full-grown male, whose great size, powerful frame, and demoniacal expression fully entitled him to the appellation of a "British tiger."

The otter, Lutra vulgaris, still survires, though gradually yielding to persecution. I have long felt satisfied that the depredations of this beautiful and graceful qualruped are far less serious than is generally supposed. In the smaller streams and burns they certainly consmme a number of trout, but, as a set-ofl to this, they

- The still popular belief that this speeies is the somed of om donestie stock is incorrect. The anatomien! distiuetions are sufficiently obvious to settle the question. A (ierman traveller, Dr. Riuptel, is believed by 'lemminck to hive discovered is speries of cat in Abyssinia from which at some remote periol our nseful mousers derivel theil origin, hut our own aceomplished zoologist, Bell, eonsiders that " we have yet to seck for the true original of this useful, gentle, mà elegant animal." 
kill quantities of pike wherever that roracions tish has contrived to establish itself. Is to salmon, they rarely eapture oue of consideralile. size. While the arch-enemy of the species, the seal, Phorel ritulinu, has become quite a rane visitor to the month of the sper. I have seen a greater number in one day off the Moy, in Killalla Bay, than could probably now be observed duringr an entire season on the sonthern sinle of the Moray Firth.

'The common hare, lorpus timidus, is widely. distributed thronghont the lower parts of the comntry, and during the autmmual months is perhaps more numbrous among the crorse-covered Wastes and peninsulas. and in the alder woorls skirting the hatuks of the sipey, than elsewhere. 'The hlue, or momntain hare, Iepms corvalielis, is not mot with in this district, and is of nnnsund ocenrence even on the neighbonring hentls of Altmoor and White Asls: while in the highlands of Bantishire it takes the place of its congener. and is far more common than weleomo in the dere forests of Glenfiddich and Bheliwater. When erossing the birch-chat glens and corries of the former, the ever-watchful ror, cerrus inprerlus, will oecasionully spring up in the path of the stalker, but that animal is so thinly distributed 
in this comparatively open country as seldom to interrupt his sport. Its farourite hamts are in the fir forests and plantations, and it is perhaps nowhere more numerous than in the great woods near Gordon Castle, from which, alas! the red deer, Cerrus slaphus, has latterly been extirpated. From time immemorial these monarehs of the race had dwelt among the primeval pines that stretch away in the direction of Keith, and many a stirring event, hesides the report of a rifle, must have varied the monotony of their domestic lives. In the library of Gordon Castle, suspended from the ceiling, are the skulls of two stags, with the tynes of the antlers still inextrically locked togrether, just as when they were diseovered in fatal conflict, by one of the keepers, at the botton of a deep gorge through which the hum of Fochabers pursues its earlier comrse. One was already dead, the brow antler of his more powerful antagonist laving transfixed lis neck and severed the jugular rein. Besides these, some of the finest "heats" in seotland were formerly obtained in this locality, and atom the walls of the same apartment; but these golden dayss were drawing to a close. In 1849 the fital edict was

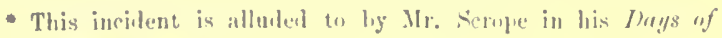
D)er-stalking, page 15. 
issued by the late Duke of Richmond. The work of extermination commenced, and was so effectually carried out that before loug the sole surviving stag, like "the Last of the Molieans," disappenred from his native woods. Althongh formerly the mumber of the red deer was regularly angmented during the winter months by recruits from the distant forests of (rlenfiddich and Blackwater, not eren a stray visitor is now ever known to make his appealance there, which may be attributalle rither to the complete extirpation of the original stock-probubly the chief attraction to their. Highland hrethen - or to the great inuprosement in the pasture that las since taken place in the libll forests. Lomgr namow strips of the heather are ammally hurned in different spots, and in the following year a crop of verdant grass springs up, affording ample pastumere to the herds, as evincerl not only by the greater weight of the stans themselves, lut hy the inereased development of their antlers. Indered it is only during execptionally serere seasons that they uow find any indurement to wander, or suffer from privation, as in the memorable winter of 1 sti.s-titi. when, after the meltiug of the suow, an unhilply" fumily, consisting of thirty-four red leer, onte fox. and nine grouse, were diseovered in the lottem of 
a corrie, where they had been either frozen to death or smothered in a drift. 'Truly " misery makes one acquainted with strange hed-fellows."

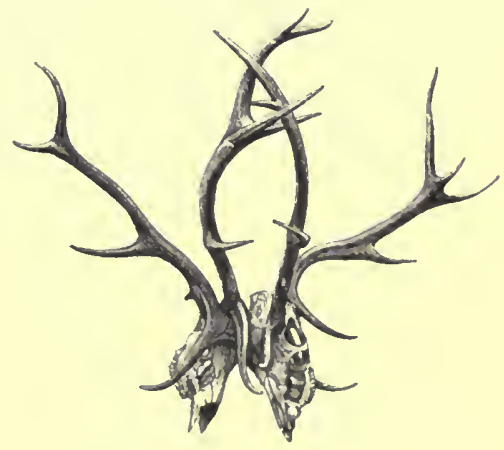




\section{SPEY FLIES AND WADING GEAR.}

" Nec minus atque alios fallet tibi dredala musca Artifici distincta manu plumâque tenclla Consita."

$$
\begin{aligned}
& \text { Jasies P'акk: (Lord Wensleydale), } \\
& \text { C'embridye Tripos Verses, } 1502 .
\end{aligned}
$$

'Tue golden period of sport for the angler on this portion of the Spey is from the 26th of August to the 15th of October. On the former day the nets are taken off, and on the latter the rod-fishing seuson eloses. The pools during the carly part of september generally contain a fair supply of newly-run salmon and grilse, although the dry weather which prevuls at this time of year on the Morayshire const seldom fails to afleet the depth of the water injuriously, and to contine the fish too much to their respective quurters, until the first welcome antmmanl spate sets them free. The tenants of the lower pools then move higher up the river, and shoals of tine sulmon that have long been congregating outside the estuary, and 
anxiously watching an opportunity of quitting the sea, now cross the bar and occupy all the favourite haunts in eonsiderable numbers. When the river has settled down after a real effective flood of this sort during September, good sport may be anticipated until the end of the season, and a second spate is rather to be deprecated than desired; for although it never fails to hring up fresh recruits from the sea, yet the same instinct that prompts these to enter the river equally induces those it already contains to more higher up the stream, and during their change of quarters success is out of the question, for a "travelling" fish nerer takes the fly.

It is a fact that this portion of the Sper-the last ten or twelve miles of its course-nffording such good sport during the antumu, is totally unproductive to the angler when the river opens argain in the spring, and for some time afterwards. The salmon are there sure enough, and are netted in considerable numbers, but they are all "travellingr."

Fly-fishing is then hopeless, and suceess cannot be expected nearer than Arndilly or Aberlour : higher up it is still better, thomgh as the year advanees these conditions are gradually reversed. Salmon, as a rule, generally become searcer on 
the approach of summer, while, on the other hand, the great influx of grilse commences about the same time. In Angust, the heavier fish begin to renppeur, increasing in weight as the yenr progresses, and the grilse sensibly diminish in numhers; but it is not until after the 26th of Angust, when the nets are removed, that the fly-fisher on the lower waters finds everything in his favour, and may then fairly cousider himself on the best part of the Spey.

Notwithstanding the flood of light that has been thrown of lnte years on the biograplyy of the salmon by patient olservers and zealous piscienlturists, how much still remains unknown and obsenre! If any long-disputed point lans latterly been more satisfuctorily settled than mother, it is that the parr, the samlet, the grilse, and the salmoni are really hut one and the same fish at different periods of its existence; yet, but a few years ago, one of our most distinguished iehthyologists assured me that the parr was a distinet species. Wamed by the errors into which eren scientifie luminaries may acensionally fall when dealing summarily with questions so full of difficulties, I shall aroid every "querstio rexutu" comnected with the history of Silmo salar; but in reference to the fact to which I have just alluded, 
and which appears to many persons so mysterious and unaccountable, I venture to think the solution simple enough.

Assuming the correctness of the generally received opinion, that all salmon enter fresh waters for the same purpose, and are impelled by no other instinct to leare the sea than the desire of ultimately depositing their ora in the gravelly shallows of their native rivers, we may surely conclude that these early fish are "told off" by a never-erring Providence to occupy at a future time the upper spawning-heds, and, having a long journey before them, are "trarellingr" on their way to the higher portions of the river, in ohedience to that first law of Nature, "Increase and multiply."

Spey flies, properly so-ealled, are simple and unassuminer both in composition and appearance, yet they are tied with as mueh skill and enre hy the lest native artists as is exhibited in the fuhrication of the most complieated, grmuly lnes, fornierly imported from Ireland. but now equally well known on the Shannon and the 'Treed, and many other Scottish as well as Norwerrian rivers. It is true that, of late years, some of these showy strangers have been introdued here, and nuder certain conditions of sliy and water are found 
more effective than any of the aboriginal type, but, as a general rule, I have found that newlyrun fish in the lower waters are more readily enptured with flies of the modest native pattern than with the most brilliant exoties that can be produced by a combination of hmmming-hird, huse and yellow maeaw, orange-breasted toucan and the variegated metallic plumage of the golden pheasint.

The term "fly" is clearly a misnomer. No insect that ever winged the air hears the slightest resemblance to any of these artificial lures. and even if it did, the motion impurted to the latter muler water would be muntmal and impossible. They are eridently takem by the salmon for some of the numeroms varioties of crusteren-prawns, shrimps, fe. - which, with echinodermata-starfish, Se.-constitute his rich repast in the depths of the ocean. A conviction of the aecuracy of this surmise forced itself upon me a few years ago, while lying town on the hank of a small clear pool, at the tail of a rush of water thromerh one of the lesser arehes of Spey brilge, near Fochahers, and attentively watching the motions of a fly at the end of a long line thrown by a young friend of mine-an aceomplisher fisherman-from over the parapet above. Its umdulat- 
ing morements under water exactly resembled those of a living shrimp or prawn, while the eontinuous play of the long soft hickles of the heron or fowl-so eharacteristic of the old Spey fliesimitated still more closely the actions of those small, but many-legged crustaceons amimals, as I had frequently observed them in the aquarium of the Zoological Society.

Notwithstanding the subdued tone and apparent simplicity of all these Spey flies, and a certain family resemblance, if I may use the expression, that pervades them all, yet after a little practice they may be easily distinguished from each other, and however trifling and insignificant these minute differences may appear to the uninitiated, yet in the eyes of the experienced native fisherman they are of considerable importance, and when salmon are shy, suecess is frequently supposed to depend upon their due appreciation.

It may be hardly necessary to observe, that the component parts of each sort of fly are maflected by its size. 'This varies considerably. 'Those which are in vogue during the spring months in the upper waters, when the river is excedingly high and rapid and the pools unmsually decp, being really enormons compured with their minute representatives which are generally found most 
suecessful in the summer months and early autumn, but mueh must be left to the judgment of the fisherman himself; there is no rule without an exception, and I have frequently found it necessary, after a moderate rise of the water, to employ flies twice as large as those which I liad found of faultess dimensions but a few days before.

'The following is a list of old Spey flies. To every fisherman on the river it will be sufficient to say that the deseriptions are taken from specimens tied by that necomplished artist, Shunks, of Craigellachie, of whom Mr. Barney Maguire, if he had ever visited the spey, might perhaps have sung :-

There's Mister Shanks too, upon the banks too, Och that's the fellow that can throw a loine, $A$ clever boy too, he can tic a floy too, For art und practice he does both comboine.

\section{Old Sier Flies.}

N.B.-The dubbing-or bolies-of all these thies is composed of Berlin wool.

Gold Sreat.-Is generally on a large lrook. l3ody bluck, with only two or three turns of very broud gold flat tinsel and with a single turn of fine silver beading between the bars 
of the tinsel. Red cock hackle, very soft, taken from the tail coverts of the bird. Wing, mallard.

Silver Speal.- Same as above, but the flat tinsel is of silver and the beading between the bars of gold.

Golo Refach.-Body black with three hars of flat gold tinsel, between which are three rows of very fine gold beading. Tip of the tail sometimes finished with orange silk. Red cock hackle from the tail coverts--soft and fine-along the body of the fly. Shoulder lackle of teal or gninea-fowl. Wing, mallard. Silver Refacir.-Same as above, exeept that silver tinsel and beading are used instead of gold, and grey cock hackle along the body of the fly instead of red cock hackle.

Gold-green Refach.-Body olive, composed of a mixture of red, green, and purple fine Berlin wool. lied enck hackle from the neck. T'insel and beadingr same as in grold Recach. Shoulder hackle and wingr ditto.

Sibver-greme Remach. - Same as above, but with silver tinsel and headinger instend of gold. (Gold-greex Fly.-D) Dhbing the same as in green Reeach. Three or four turns of gold tinsel, according to its width, and between each of 
these a single turn of orange silk. Red cock hackle. Wing, teal or grey mallnrd. Silver-green Fly.-Same as above, but with silver tinsel and grey cock hackle.

The flies known as "Kings" are characterized by having alternate bars of gold and silver tinsel. No beading of any kind.

Green King.-Body same as green Reeach. Alternate hars of gold and silver tinsel. Red cock hackle. Shoulder hackle, teal feather. Wing, mallard.

Perret King.-Borly lake colour, composed of searlet and purple mixed. Alternate bars of gold and silver. Hackle, srey or red cock, according to funcy. Shoulder hackle, teal. Wing, mallard.

Buack Kisci-Body black. Alternate hars of gold and silver tinsel. Hackle, hlack cock.

Shoulder hatekle, gruinea-fowl. Wind, malland. Goln Punptes Fux, commonly called "GoLd Purpy."-lBody purple. Red cock lanckle, with hars of gold tinsel. Wing, mallard.

('vimpars Fly.-Thlis is generally tied on a larege hook. Body llack. Bars of silver tinsel, ratleer far apart, and between each bar two threals of silk, one orange, and one yellow. Hackle, jet-black cock. Wing, grey mallard. 
Gold Herox.-Body black, with bars of gold tinsel. Between the bars two threads of gold and silver beading. Hackle very long, of the slate-coloured back hackles of the heron. Wing, mallard.

Buack Hrrox.- Sume as the last, but instead of the slate-coloured back hackles of the heron. use the tips of the black feathers from the breast of that bird.

Carron Fly.-Body orange, bars of silver tinsel. Hackle, black feather from the breast of the heron. Wing, mallard.

Several varieties have of late years been added, which, though modest and umassuming compared with the gaudy exoties to which I have already alluded, must still be considered innovations, partaking as they do, more or less, of the plumage of the golden plieasant; they are consequently omitted from the ahove list, which professes to be nothing lut a brief descriptive catalogue of old Spey flies.

Certain of my sporting friends have snggested that I slould introduce into some part of this little book my opinion of the relative merits and disadvantages of the nsual waling costumes, the result of personal experience, and especially in 
comnection with a subject respecting which a widespread popular error still exists.

Whatever modifications these water]roof garments may exhibit, according to the taste or ingenuity of the various makers, it will be sufficient for my purpose to class them under two heads, viz., long boots, or stockings, pulled up separately on each leg and extending above the lince or nearly as high as the hip, and secondly, complete Macintosh trowsers-or overalls-in one piece, reaching as high as the waist, or, hetter still, up to the arnupits, over a jersey vest, where they are usually tightened by a ruming string or trupe, and kept in position hy short braces over the shonlders. Cont and waistcont are of course dispensed with in this costume.

Dismissing the Macintosh stockings from our consideration, as they possess lut one merit-lirlitness or portability-let us confune our attention to the long hoots and the trowsers.

'The boots may be made of thick leatler', snels as are worn ly all professional herring-fishers, or of thinner waterproof material of the same kind, or-best of all in my opinion-of vulcanized indin-rubber externally, down to the ankle, the feet of thick cowhide, and the whole lined throughout with soft, flexible leather. 
The great adrantage of these boots consists in their excessive warmth. They should be very large and capaeions, especially in the feet, so as to admit of the introduction of horsehair soles at the bottom, and, if necessary, two pair of long, thick worsted stockings, pulled over the legs of a pair of ordinary tweed trowsers. Fortified in this way, I have repeatedly waded for hours in rapid streams, when the temperature of the water was freezing, from molted snow, withont experieneing the slightest chilliness or inconvenience.

When the sides of a stream or pool, along which it is desirable to wade, are known beforehand, or in ordinary shallows, these boots will answer all purposes, and are exceedingly comfortable and convenient, but where it is important to advance into deeper water, with an uncertain footing among slippery conical rocks helow, to reach a goodly salmon that has been rising at a tantalizing distance; or when makingr a royagre of diseovery among the labyrinthian mazes of the last three miles of the Spey, which perhaps have been unexplored sinee their creation by the reent heary spates; and especially if dealing with a strong runaway fish strugrgling hard to return to the ocean which he has just left, and threatening every moment to break the single gut and tiny 
hook that constitute the only conncetion between you and him, during which exciting process you have probably to cross several rapids, without much time to select the shallowest spots,- then I say that the Macintosh trowsers are to be preferred to the loots, and that the use of the latter may occasionally, even to a good swimmer, he attended with considerable risk.

Although I had frequently been "swamped" on such oceusions, when crossing rapids, yet I had hitherto always managed to get ashore without any greater inconrenience than a good ducking, and I had pet to realize the danger of wearing long boots when out of my depth. One afternoon, lowever, I was engaged with a very heary fish under cireumstances nearly similar to those described at page 21 , but the incident to which 1 am now referring, oceurred during the previous year. 'The stream was strong, the tackle delicate, and the fly exceedingly minute, so that "give and take" was the only poliey likely to be sucessful. I had already crossed two streams that interecpted me from the main eurrent, down which the salmon was rushing. when I came upon a third, ruming in at right angles to the latter, and certuinly not more than thirty fect wide, which it was, of course, necessury to cross. The shingle on the 
near shore sloped away most invitingly, and although the opposite bank looked a little steep as I threw a hurried glance across, yet at that moment I never anticipated any diffieulty in reaching it. When about half way orer, however, I found myself suddenly out of my depth, holding up my rod with one hand, and with the other trying to assist my over-weighted legs in swimming across - a far more arduous task than I had imagined. Arrived there, howerer, I found that my troubles had only just begun. I struggled in vain to elimb the perpenclieular side. I felt as if a ton weight was fastened to each leg, and at last, after repeated exertions, beenme so exhausted that, with a sudden eonseiousness of immediate danger, I dropped the rod, held on with both hands at the edge of the bank, and once more strained every effort to ascend. All in vin : so throwing myself on my buck, I suceeceldel in swimming with the greatest diflienlty to the opposite shore, and felt not a little thankful when I reached it arrain in safety.

The sequel of this adventure will probubly astonish the realer as much as it surprised myself at the time. Getting rid quickly of my water-logged boots, and throwing off my coat, I swam again across the stream and ran along the side of the 
river in search of my lost rod. The current had carried it down to the head of a shallow rapid, where, partially anchored by the weight of the reel near the butt, the top joint was still visible above the surface, nodding encouragingly in its gradual descent, and with tightened line, showing that the fish was still there. Well-" to make a long story short," as they say in the fairy tales-I recovered my rod, and ultimately succeeded in landing a newly-rum twenty-seven pounder. He was, fortunately, hooked through the tongue, and lowever clated at his capture, I certainly felt at that moment that it was due rather to good luek than to good management.

The Macintosh overalls, it is true, eamnot resist the low temperature of the water so effectually us the vulcanized india-rubber boots, lut their great superiority consists in enabling the wearer to wade much farther into the river; in finet, breast high, and even in the event of his heing earried off lis legs by the force of the stream and getting out of his depth, he will find himself, if he lans been used to swim in his clothes, more at lome than in any ordinary garments. I am aware that this is contrary to the received opinion, but experto cerde. I lave more than once put it to the proof, and only last year 
convinced several incredulous friends who accompanied me on purpose to Speyside, by swimming, diving, and floating for nearly a quarter of an hour in a perfect Macintosh equipment, including a pair of heavy brogues on my feet.

The popular belief is, that if a person gets out of his depth when wearing this waterproof apparatus, the air contained in the legs of the trowsers raises them suddenly to the surface, his head and shoulders instantly sink, and he is quickly drowned; but, assuming that the dress is properly arranged, this can only occur in cases where the fisherman is unable to swim, or where, if he luas never practised swimming in his clothes, the startling novelty of his situation causes him to "lose his head," or, in other worts, his presence of mind. He cries out for help, and in doing so, exhansts the air in his chest, when, naturally, the skull and thorax becoming the heariest parts of his person, his position is quickly reversed, and every subsequent attempt at inhalation fills his lungs still more with water, and all is soon orer. Many fatal instances of this kind lnve oceured which, of course, have only served to propugate the popular error, lut I ann inclined to think that the neglect of a very simple precuution, on the importance of which it is impossible to dwell too 
strongly, has been the chief eause of loss of life in all cases where the sufferers were known to have been previously able to swim.

I soon found that the running string, or tape, attached to the trowsers for the purpose of tightening them round the ehest, was not suffieiently close-fitting to exelude the water from foreing an entrance in the event of total immersion. I therefore tried a leather strap in addition, well buckled up, but it became relaxed when saturated, and after various experiments I found that a strong hempen whip-eord was the very thing required, as it contracted pereeptilly when wet, and, with the addition of a second round the waist, rendered everything quite seeure. I could then swim for ten minutes at a time without the intrusion of more than ahout a wineglassful of water, which gradually foreed its way through the cireumference of the flannel jersey, however tightly compressed by the cords. The well-nailed leather brognes, so fur from inconveniently impeding the flonting power, acted merely as a slight counterpoise to the partially inflated and buoyant overalls, and the satisfuctory result was simply a greater fucility in keeping alove water than I had often previously experienced when practising swimming in a loose flannel suit, or light tweed garments especially selected for the oceasion. 


\section{A BLANK DAY IN A DEER-FOREST.}

"Nature teaches beasts to know their friends."

SHAKSPEARE.

The more I see of the red deer in their native forests, the more I feel interested in their ways and habits. Indeed, almost every stalk, whether successful or otherwise, affords me some opportunity of admiring that ceaseless watchfulness on the part of the hinds, withont the exercise of which the fat and comparatively lazy stags would less frequently esenpe the rifle.

During the excitement of my first season, the paramount olject was, maturally chongh, to compass the denth of the mimal I was in quest of ; and it was not mutil the novelty of the sport had in some measure worn wwy, ufter the arquisition of several good "leads," that I began to derive new pleasure from observing the frequent exumples of their marvellous instinct. 
Besides the acute sense of smell with which these animals are endowed, enabling them to detect the slightest taint in the air to the windward of their position, they possess other gifts in a remarkable degree, by the exereise of which they sueceed in avoiding danger, and this frequently at the very moment when escape wonld appear to be most improbable.

Foremost among these is their power of reeognizing the somd, or cry, of alarm nttered by various native birds of the forest, and of appreeinting the difference between this and the orlinary roice or call-note of the species. There would seem to be no link of attachment letween the animal that confers and the one that receives the benefit, which appears to me to churacterize the exereise of this fueulty in the red deer and to distinguish the ease itself from others which at first sight minht appear to be analogous.

The author of that charming look, "The Monasteries of the Levant," lam the envinble good fortume, while stalking a crocodile on the hunks of the Nile, to corroborate the aecuracy of Herorlotus's acconnt of a singular episorle in its liograplyy, which for upwarls of two thousand yoars lum been looked upon as apoeryplual. When within u fow yurls of the sleeping monster, and just as ho 
was preparing to pull the trigger, his attention was attracted by a bird about the size of a plorer, walking up and down near the crocodile. Suddenly springing up, and nttering its cry of "ziczac"-by which name it is known in Egypt*-it flew several times against his head and fuce, to give the alarm, and so suecessfully, that before the narrator of the adventure conld fire, he was covered with mud dashed over him by the great reptile as he rushed into the river. Herodotus's account is as follows. "I proceed now to describe the nature of the crocodile....... Living in the water its throat is always full of leeches: heasts and birds universally aroid it, the trochilus alone excepted, which from a sense of gratitude it treats with kindness. When the eroeodile leares the water, it reclines itself in the sand-and generally towards the west-with its mouth open; the trochilus enteringr its throat destroys the leeches; in acknowledgrment for which service it never does the trochilus injury." +

Geoflry St. Hiluire admits the fact, lut says that "the bird enters the montl of the crocodile attracted, not by lecehes, bnt lị a small insect like

- The zic-zac in the reoxinos of Herodotns and the Charadrius Eyyptiacus of morlern ornithologists.

+ HELOE's IIcrodolus. 
a gnat." * At any rate it can no longer be doubted that a link of attachment between the two ereatures does exist, and that in all probability the bird is in the habit of feeding on the small flies and numerous aquatic insects either adhering to the crocodile itself or exposed on the slimy surface of the mud during his passage from the water, and admitting at the same time the truth of Rochefoucault's celebrated definition of gratitude, there can be no difficulty in believing that the zic-zac is prompted by selfish interest to kecp wateh over the huge saurian who supplies lim with such a well-furnished larder, and habitually to aet as his sentinel on those ocensions.

Anotler instance of this kind is mentioned in Gordon Cummingr's "Sports of Southern Africa." Here the rhinoceros enacts the part of the crocodile, and is carefully tended by a swarm of little hirds, of the stroling family, who accompany lim on all oceasions, performing the same duties for him, when asleep, that the ric-zac fulfils for the crocodile; sereaming and fluttering, and dashing at his eyes on the slightest approach of danger: lont their motives are evidently not disinterested, for when unalarmed they may be se'm continually feeding on the parasitic inseets that

* See also Bishop Staslefy's Familiar History of Birds. 
infest his skin, or on the flies that perpetually buzz about his ears and head. So faithful, indeed, is their allegiance, that they adhere pertinaciously to the back of the rhinoceros, when in full retreat, and instead of deserting him as he rushes through the trees, or under the loughs, they merely dodge to the opposite side of his body, or erecp under his belly, maintaining their hold with their claws until the danger has passed away, when they resume their position on his back. In this case even the most sceptical must admit that the services of the bird to the object of its eare are not gratuitous, and it seems to furnish presumptive evidence that the attachment of the zie-zac to the crocodile is of a similar nature.

Now for my own experience of an analogrons ease.

Many years agro, in the west of Ireland, where I served my youthful aplerenticeship to every wild sport that the British Islands ean afford-exerpt deer-stalking-I used to vary the salmon and trout-fishing, during the summer, by an ocensional senl-shooting (xpedition on the sandhills and islands ontside the river Moy, in Killalla Bay. At low tides, whon these hanks were left uncovered, great numbers of sonls used to crawl up the slopes of the lesser islcts and indulge in a somd 
slumber, in full enjoyment of the warm sunshine. It was impossible to get within rifle-shot in an open row-boat, as the sound of the oars, even when muffled, soon reached their ears and alarmed them. Now and then, while I was mackerel-fishing in a suiling-boat, a seal would perhaps indisereetly raise his head out of the water within thirty yurds, and us I always kept a rifle ready for such a chance, I occasionally succeeded in bagrging one after a long chase, the first shot rarely proving fatal, although sufficiently severe, perhaps, to compel the animal to reappear on the surfuce in less time than if he land not been budly wounded. Then commenced a chase in the row-hoat, the seal repeaterlly diving, but each time remaining for a shorter period under water, until at last I could get near enough to shoot him through the head, while the man in the bow would endeavour, thounh not always successfully, to secure the prize with the hont-look lefore it sank lifeless muler the surface.

Far different tacties were neessary when tryiner to eireumvent the seals as they dozed on the sandbmks. Watehing mutil the tide had more than half petired, and ulways before the ebl, I used to concenl myself in a light, shallow, flut-bottomed punt, where I lay on my face, eovered with sea- 
weed, a rifle projecting from one end and a paddle from the other, the occasional use of the latter enabling me, without any noise, to keep the little craft from turning round, although entirely propelled by the receling tide. Occasionally I could suceed in getting within shot, if the slumberers happened to be unattended by a great blatek-lacked gull, Larus marinus; but that was a rare erent. A bird of this species, and one only at a time, generally stood near them, and no sentinel erer kept more faithful watch. As soon as I used to perceive him I knew that all chance of bagring a seal was over for that day. He was a capital judge too of distance, for he would stand patiently, and quite immorable, on one leg, apparently regirdless of the olject that was gradually nearing the banks, or pretending not to see it, nutil I was almost within shot, when suddenly he wonld rises, and fỵing romed and round over the seals, alarm them at once, nttering all the time his loud, tanuting laugh. T'uming mpikly "right abont finee" they wonld hoblule down the bank and soon disappeas in the water, while their protector, not sutisfien with having baulked me of my sport, would licrep at a safe distunce over nuy hear, and, adding insult to injury, eontinue to repent his jeering notes, until at last they gradually died away in the distance. 
I have frequently found fragments of salmon and different speeies of sea-fish on isolated rocks and sandbanks in rarious parts of the hay; doultless the remains of many a repast left by the seals, and duly appreciated by their grateful attendant. The number of grilse and salmon taken with the fly-as well as net-exhibiting severe wounds from the paws and teeth of the seals, is well known, lut it is insignificant, eompared with the quantity devoured by them; while many others, again, escape for the moment, only to die ultimately of these injuries, before they cun ascend the stream; and as, after the commencement of decomposition, their bodies soon flont on the surface of the ocen, they fumish a plentiful supply of food for this large grull, who, being unable to dive, is in fact nothing better than a marine scavenger. Doubtless he fully apprecintes the important services rendered to him lyy the senls, and it is quite reasonable to suppose that he is not influenced by disinterested motives in neting as their guardian angel.

Between the red deer and his feathered friends there would seem to be no such tender tie. His instuntmeous appreciation of any sound or morement on their part, indicating the slightest suspicion of approaching danger to themselves, 
appears to be the result of hereditary instinet aided by acute observation. These reflections hare been foreed upon me by the experience of a single day's stalking in Glenfiddich forest last week. Everything looked favouralle on that morning as I left the lodge with the forester, MeKay, attended by his brother Joln, the gillie, leading the two deer hounds. A steady breeze, neither too light nor too strong, was blowing right down the glen from the south-west; the day was perhaps oceasionally a little too bright, as the sun every now and then peeped ont from the grey clouds, but we expected no diffieulty in finding deer, especially as a large herd had been alarmed on the previous evening in the adjoining forest of Blackwater, and had been seen to cross over the ridge of Cook's Cairn to the upper part of Glenfiddich, in which direction we were now proceeding.

After following the eourse of the stream on the right bank for a couple of miles, we halted, and examining with our glasses the sides of the eorries opposite, we soon discovered several small herds, consisting principally of hinds, and the few stags that were among them did not seen, to the experienced eye of the forester, suffieiently tempting, either by spread of horn or size of 
body, to induce us to think more about them. After another half-hour's walking we again came to a halt, and reconnoitred the sides of the hills in all directions. There was one steep corric on our left, through the centre of which a burn ran down in the direction of the river. I few birebtrees fringed its sides, intermixed with occasional fragments of rock, while still higher up, large patches of bright green, where the heather had been burned and the grass had recently frown, afforded a beantiful contrast in colour to the wider extent of purple in which they seemed to he embedded. In the midst of one of these verdant spots we soon made out several deer, some grazing, others lying down, and seattered here and there at a distance from the main body, several hinds higher up the hill, and a few others elose to the birches near the banks of the burn.

I soon perceived that there were about half $a$. dozen stags among them, and at least two with fine heads. This was encouragring, but on looking round to the forester, who had just shut up his glass, I knew at onee from the expression of his countenanee that he did not share my samgune expectations. One, he admitted, that was lying down. was a "grand beast" with a roval heal. He recognized him at once, having stalkel him in 
vain last season two or three times. On the present occasion the position of the hinds was the cause of his anxiety. Most of them were grazing on the other side of this stag, from which direction alone we could renture to approach them, as the wind was blowing right up the corrie. They might perhaps move lower down in the direction of the river a little later in the day, and as such a chance as this was not likely to occur often, we decided on continuing our course up the main glen for a considerable distance, and after crossing the Fiddich, that we should ascend the opposite hill, climb the ridge overlooking Blackwater forest, and then, turning back, lieep the heights a little above us on our left, until by this circuitous route we lad arrived opposite the hear of the corrie in which the deer were crazing. This would ultimately bring us to leeward of them, and at the same time afford the best chance of getting within shot of the big stag in the event of the hinds and the rest of the herd moving lower down, and that we could sucecel in crawling over the bare rilge of the hill and reach the commencement of the burn mobserved by them.

We had already carricd out almost half of this programmo; had crossed the stream a couple of miles higher up, and were toiling through a small 
eorrie, with the intention of emerging from it at the other end, over the crest of the hill, when MeKay, who was leading, suddenly stopped, and dropping on his linees, motioned to me to lie down-the gillie with the dogs, of course doing the same. On creeping up to him I found that he had got a glimpse of a stag grazing on the hill to our right. We had nothing to conceal us but the heather, which, however, grew thickly near the course of the burn, so crawling through it, in sualie-like fashion, we at last got within about three hundred yards of him. Then I ventured to look. There he was: grazing leisurely: a beautiful lroadside shot: standing off distinctly from the dark hackgromud. He had a fair head, of ten points, and appeared in eapital condition. Not another animal of his own species was within sight. Several tussocks eovered with mosses and lichens rose within rifle range of him, and once there, I conld hardly fail of killing him. Indeed at that moment I felt eertain of success, as the intervening ground was well fumished with heather, and we had already overcome the chief difficulties in reaching our present position. Quickly resuming our task, we had accomplished about a quarter of the listance, when a cock grouse sprang up, right in front of Mcliay, and flew back over our heads, 
down the corric, quite away from the stag, uttering all the time his loud, half-crowing, halfscreaming cry of alarm. Looking up at the same instant I had the mortification of sceing the deer bounding away at his best pace up the hill, and could only gaze helplessly at him until he disappeared over the brow. As for the forester, this was too usual an occurrence to disturb his characteristic equanimity, or to elicit any audible demonstration of fecling on his part.

We had still the big stag in prospect, and another hour brought us over the ridge and round the hills to the top of the corrie in which we had seen him and the herd of deer that accompanied him. How my guide hit off the place where it was necessary for us to halt and crawl up the slope to our left, secmed marrellous to me, but when on the summit itself I saw at a glance that he had conducted me to the very spot, although I could discorer no landmark of any hind that could lave assisted him. Here we slowly raised our heads, and noiselessly opening our glasses examined the sides of the corrie. There was " the muckle hart," still lying down, and we saw that most of the hinds we had previously olserved between him and our present position had fortunately grazed nearer the river on either side of 
him, so that if we could only get over the first thirty or forty yurds of the erest of the hill, which was naked and slaty, without being observed, we might reach the burn and some birch-trees, after which the banks, although low, would suffice to screen us from the hinds as we crawled through the bed of the stream. Leaving the gillie, therefore, and the dogs at the other side, we commenced operations by turning over on our backs and halfsliding, half-wriggling, feet foremost, down the steep ineline, we successfully accomplished this, the most difficult part of our task, and then commenced crawling over the stones in the bed of the burn, every now and then immersed in a pool of water, as the banks were still too low to admit even of a stooping posture. At last we gained the friendly shelter of the birch-trees, and rising to our feet, alvanced with comparatively little difficulty mutil we reached the hase of a naked elevated mound overliunging the bed of the stream, which afforded an opportmnity of uscertaining our exact position. Slow and stealthy was our progress as we erept up to the ridge of the rough slope, when I rentured, as eautiously as possible, to peep into the glen below. It was a magnificent sight. 'There, within three hundred yuds of me, was the lig stag, still lying down, lut with his 
head turned away from us. Eren when thus foreshortened, he looked a giant among the others, two or three of whom, as well as several hinds, were grazing on either side of him. The wind too was all right, and MeKay urged that no time should be lost in backing out of our present position as eautiously as we had reached it, and after returning by our former track to the burn, that we should crawl down it again as far as a stunted bireh-tree on the same side of the bank, not more than two hundred yards off, under eover of whieh I could get a broadside shot at the stag when he rose from his lair and commenced feeding. Before retiring, however, I conld not help throwing one more admiring glance on the landseape below. The lofty hill of Corryhabbie, and beyond this the still higher Ben liennis, with white clouds eapping its summit, rose at the opposite side of Glenfidlich, while a limited view of the middle distance, inmediately in front, was bommled to the right and left by the sirles of the eorrie which in dark shadow seemed to frame the sides of the pieture.

Hardly laxd I oltained more than a glimpse of this lovely scene when a distant croaking sound attraeted my attention. I had no diffeulty in recognizing it, although it was the first time I 



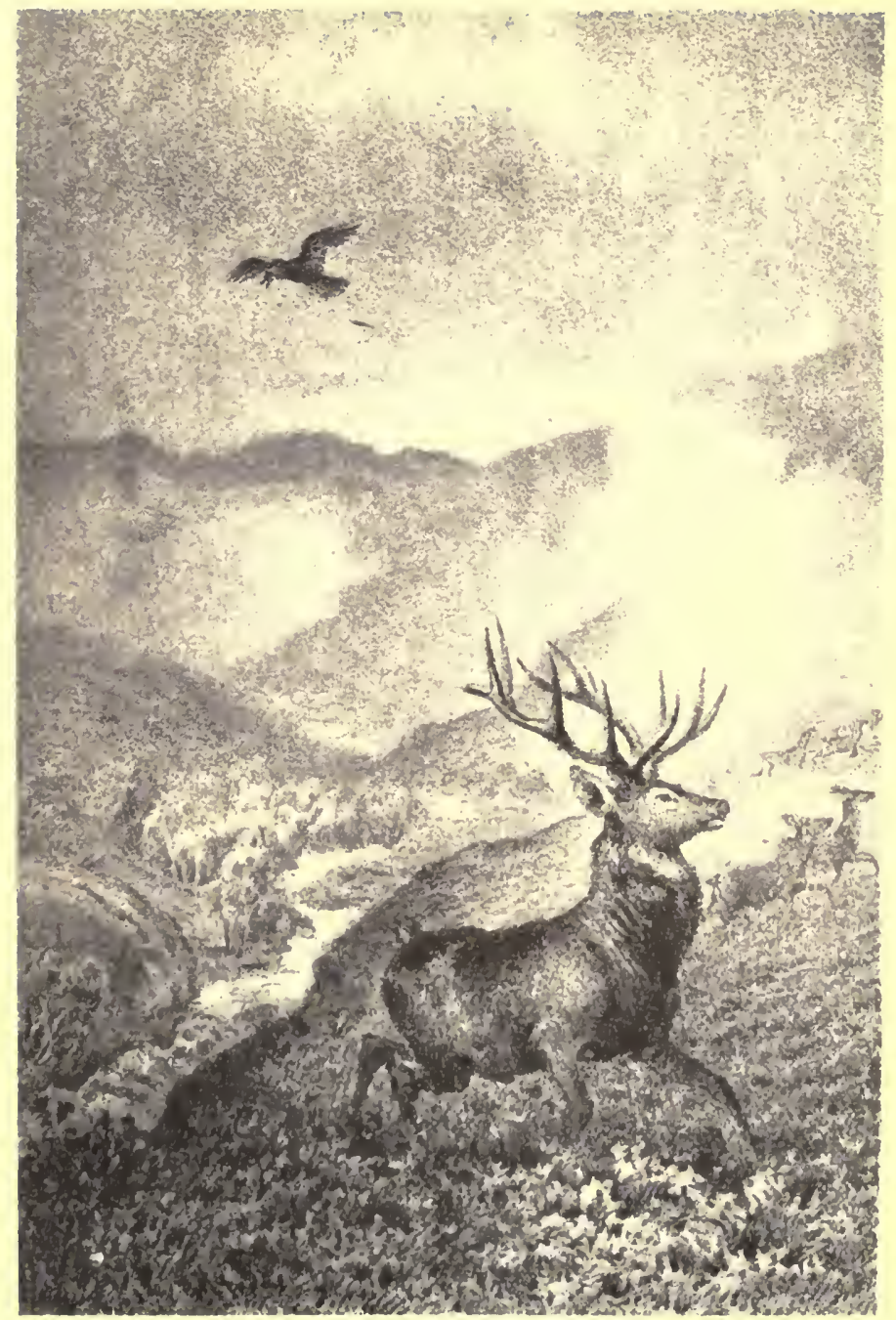

JIIR I31,ACK INHURMER, 
had heard it in a deer forest, and for a few moments it caused me no apprehension. Sudilenly, however, the deep, hoarse notes, that at first liad reached my ear at regular intervals, were followed by a succession of rupidly-repeated angry barks in a higher key. 'These soon became louder and louder, and turning up my eyes, I saw, to ny consternation, just over our leads, a large raven. He had come orer from Blackiwater forest, in our rear, having probahly got sight of the gillie with the dogrs on the other side of the hill. Now he evidently perceived us and redoubled his warnings, swooping round and eireling directly orer us. In a few secomls all was over. Away wont the hinds. Last of all uprose the stag himself, slowly and leisurely; at first looking round him proudly, us if disdaining to take alarm from so slight a cause, and at the same moment revaling his grand proportions and his magnificent sprending antlers. 'J'hen, having upparently made up his mind in which dircetion to retreat, he trotted up the sicle of the corrie in the track of the funitive hinds. Presently we suw the whole herd slacken their puce and, ono by one, disappour orer the hill; until, at last, "the monareh of the grlen" himself loomed in darli profile on the sky. line, and then ranished from onr sight. 
"Bad luek, that, MeKay," said I, scarcely able to restrain the bitterness of my feelings. I could see that my companion fully shared them, and that this second misfortune was too much for his stoicism, for among the mysterious sounds issuing from his mouth, as he slowly inserted a consolatory quid of tobaceo within its precincts, I could occasionally detect an imprecation on the head of the "doom'd corbie" that had spoiled our sport and robbed us of the finest stan in the forest. 


\title{
FLOODS ON THE SPEY.
}

\author{
Bursside Pool.
}

" Th" expanded waters gather on the plain, They float the fields and overtop the grain :

Then rushing onwards with a sweepy sway, Bear tocks and folds and labouring hinds away.

Nor siffe the dwellings were; for sapped by toods, Their houses fell upon their householl gorls."

Drydes's Virgil.

"Piscium et summo genus hasit ulmo, Nota qua sedes fuerat columbis."

HORACE.

At this season of the year the occurrence of at flood suffieient to overflow und devastate the eultirated fields above the banks of the spey, is a rare erent, although I have witnessed sudden sputes ufter heary falls of rum in the Highlands, during which, the water's rose many feet in a few hours, and tir-trees, framents of buttresses, and dehris of all kinds, were swept down the stremm; the round houlders and stones at the same time, as they rolled along the sides of the river, somding 
like a continuous fusillade of distant musketry, while the whole scene enabled one to realize what the result must be when the mighty river is in earnest and rushes down in full force.

Of all the visitations of this kind that have oceurred in the north of Scotland, none ean compare, for extent of area and destructive effect, with the tremendous flood of the $3 \mathrm{rd}$ and 4 th of Angust, 1829. Ruin and misery were indeed universal, not only on the Spey, but along the course of all the principal rivers in Morayshire, Banffshire, and a great part of Aberdcenshire. The deluge of rain that was the immediate cause of this unprecedented calamity fell eliefly on the Monadhleadh mountains, between the south-eastern portion of Loch Ness and the sources of the Findhorn, and on the Cairngorm range-part of the Grampians. The country albove Kingussie would appear to have eseaped, but all the cultivated ground in the neighbourhook of the Spey, from thenee $t o$ the sea- $a$ distance of seventy miles-was inunduted ly the waters.*

- A most interesting aceount of this memorable event was compiled soon afterwards by the late Sir T. Dick Lauder, to whose pages the reader is referred for a mimute description of many a fatal struggle, heroie rescue, and hairlirealth escape, during the floods on this river and its tributaties, as well as on the Findhors, the Nairn, the Deveron, and the Dee. 
To refer only to a few examples of devastation during the last twelve or fifteen miles of its course; the district with which I am most familiar.

Near the mouth of the Fiddich-one of its principal tributaries-the upper part of which runs through the deer forest of Glenfiddich, the farm of Dandaleith was converted into a perfect desert, " great extent of rich land covered with sand and gravel, "all the corn-stacks floated off" like a fleet of ships, and a thriving distillery was overwhelmed."

Abont five miles lower down, nearly opposite Ben Aigen, the village of liothes, though somewhat elevated above the plain, was nearly submerged, and scveral substuntially-lunilt houses either partinlly or totally ruined; while at Orton, on the left hank of the river, helow Bont o' Brig, upwards of a hundred acres of crops were destroyed, and fifty more carried away, or rendered valueless for agriculturnl purposes.

At the small town of Garmouth, near the mouth of the Spey, many houses of two mur even three stories lighl were half thrown down, the whole plain, as far as the eye could rench, was covered with water, the shores of the harbour studded with stranded ressels, and even the sen- 
beach strewed with the earcases of animals, including " millions of dead hares and rabbits."

But the most memorable ealamity on this part of Spey was the destruction of the great bridge of Fochabers, near Gordon Castle, spanning the river on the high road between Keith and Elgin. "It consisted of four arches; two of ninety-five feet and two of seventy-five feet span each, making a total waterway of three hundred and forty feet. On the moming of the 4th of Augnst, the entire plain, from Ben Airen to the sea, presented one vast undulating expanse of dark brown water, in some places more than two miles broad. The floating wrecks of nature and of human industry and comfort were strewed over its surface, which was only varied by the appearance of the tufted tops of submerged trees, or hy the roofs of houses, to which, in more thin one instance, the miseral,le inlabitants were secn clinging, while boats were plying nbout for their relief. And still the elements raved with unalated fury, so that not a bird could dare to wing the air." +

Several persons were on the bridge during the early part of the day, looking over the parapets at the wreck, carcases of dead animals and other

* Sir T. D. Lauder. + Sir T. D. Lauder. Op. cit. 
hodies whirh were hurried through, but most of these had subsequently congregated at the Bunffshire extremity, to witness an attempt on the part of the forester and his men to protect the momnd of approach, when suddenly a fissure appeared in the very centre of the path, immediately above the second areh on the Morayshire side. Those who were nearest ran for their lives, giving the alarm to others; and, a few seconds afterwards, down went the whole mass of the two arehes on the left bank of the river, carrying with it a lame youth, who unfortunately had not been able to effect his escape.

For some years afterwards passengers and goods were conveyed across in hoats, until un Act of Parliament in 1832 enahled the trustees to ereet a single wooden areh in place of the two that were destroyed-thus dispensing with the necessity of a pier in the most rapid part of the stream. This, at the time of its erection, was the largest of that deseription in Britain,* but as the work showed symptoms of decay in 1853 , cast iron was sulstituted for timber; the arch was completed in two years, and has ever since effectually resisted the foree of the waters.

Althongh such a calamity as this terrible deluge

- Dr. Losgmerr's Speyside. 
of 1829 has not since occurred, yet the winter torrents are generally powerful enough to overflow the left bank of the river, and, in spite of groins, buttresses, and other contrivances hoth expensive and laborious, large gaps and chasms are frequently exposed after the sulsidence of the floods, and the work has to be commenced anew.

For six or seven miles above Fochabers bridge, the alluvial and comparatively flat tract, which suffered so much, is still the site of some of the richest and most highly-eultirated farms in this part of Scotland, forming a remarkahle contrast to the opposite side of the river, with its preeipitous sandstone cliffs and lofty hills, elothed with pine-woods, extending into the interior in an easterly direction. The lands of Dipple were remarkable for their fertility, and shared a celehrity with some others, as recorded in the following old rhyme,-

" Dipple, Dundureus, Dandaleith, and Dalvey Are the four fairest farms on the bauks of the Spey."

At Dipple there is also an ancient cemetery, and a fish-hed was long since discovered in the same locality, which lias furnished to collectors many fine specimens of ichthyolites, but is now 
nearly exhausted. Higher up still is the farm of Burnside, and beyond it the lands and demesne of Orton.

Until a few years ago one of the best salmonpools in this part of Spey was at Burnsideimmediately opposite the gorge of Alt Derg at the other side of the river. I never knew it in its palmy days, before the annual encroachments of the stream had gradually eaten away so much valuable land that it became necessary at last to undertake a serious war of defence against these winter torrents, and to call into play all the engineering skill and resources that were available. On such ocensions, where the ground is sufficiently firm, liuge crates, strongly constructed and filled with large boulders, are found to be the best protection; these, placed closely alongside of each other and securely fastened torgether, constitute an admiralle though expensive bulwark. On the other hand, where the derastation is usually greatest, the seetion of the hank reveals a loose boulder clay, and a different and comparatively ceonomieal plan of defence is adopted, but cspecially exeerable in the eyes of a salmon-fisher. During the lieats of summer and early autumn, when the river is at its lowest, numbers of young trees-foliage, branches, and all-are laid down at 
the bottom near the shore, the uppermost boughs pointing outwards, all elosely packed together and forming a regular cheraux de frise, frequently extending far into the stream; large boulders are again heaped upon the trunks nearest the land, and then another layer of trees, the process being repeated until the work is supposed to have attained a sufficient elevation. This sort of subaqueous fence sometimes extends for a considerable distance, oceasionally interrupted, only to be recommenced twenty or thirty yards lower down, and where the banks have once been subjected to this treatment, it is easy to imagine that the salmon-fisher must seek for a more favourable spot for the exercise of his art.

The year before my arrival, Burnside pool had been fortified on the above system, and consequently deserted by anglers, but I had heard so much of its former renown, and so many rumours lad reached me of the number of large fish still frequentingr its deep recesses in perfect seemrity. that I felt an irresistible desire to pay it a visit and invale the sunctuary, although with a full knowledge of the consequenees of such an attempt. Even partial success was of course out of the question while the watre was perfectly clear and the use of single gut casting-lines and small 
flies neessary; watehing $\mathrm{my}$ opportunity, therefore, until the river had acquired a eoffee-coloured tint after a partial rise, I sallied forth one afternoon with a stiff, powerful twenty-foot rod, treble gut and large flies specially prepared for the trial. On reaching the spot I saw at a glance the difficulties with which I should have to contend. The river rolled deep and dark close to the very bank, the trunks of the trees, cmbedded in the boulders below, bordered the entire extent of the pool, and even where these were not visible I knew that the branches of others lay treacherously beneath the water in every direction. Wading was ont of the question. Livery cast must he from the shore. and far out too, where I conld already see sercral good fish rising in the most tantalizing manner. Beyond them, a bank of shingle, commeneing much higher up, seemed to divide the river into two branches, but the arm at the other side was comparatively shatlow, while the main stream near me rushed over the promontory at its head in a deep, impassal,le rapid, near which was an angular buttress projecting into the river, where I decided on commencing operations. Putting a lurge spring spey fly on the treble gnt custingline. and testing the strength of every portion of the latter, I threw into the stream just above 
where I had seen a large fish rise several times. At the second cast I had him, and away he went directly towards the rapid, springing repeatedly out of the water-a twenty-pounder at least-then suddenly turning back he bolted across to the opposite side, still fortunately keeping away from me. All this time I had "held on like grim death," showing him the butt of the rod, but his violent plunges and strenuous efforts to descend the stream severely tried the strength of the upper joints; prudence, therefore, induced me to yield partly to his wishes, and while grudgingly giving him line, to keep him at the same time as near the surface as possible. He was still, as I thought, sufficiently far from the bank to escape the branches underneatl, when, with a tremendous rush, down he went to the bottom. Sulking, thought $I$, as the line became fixed, and no response followed the movement of my wrist in attempting to rouse him to renewed activity. Then, shortening the line as much as possible, and exerting a strong n]ward pressure-trying, in fact, to lift him perpendicularly, usually a successful expedient on similar occasions-I directed my attendant gillie-it was before I had enlisted Simon-to pelt him with stones thrown from the near side, and within a foot or two of the spot 
where we supposed he was lying. All in vain; not even a twitch was pereeptible; nothing but the monotonous, thrilling sort of sensation that is invurially telegraphed along the rod when the lhook is hopelessly fixed in some inanimate objeet at the bottom. The awful truth then burst upon me. He was gone! Every attempt to extricate the tackle was unavailing: it was evidently entangled among the branches of the trees in the deepest part of the river, and as it was impossible to reach the spot by wading, I laid my rod on the ground and walked down the side of the lank in search of $a$ fir-pole, with the assistance of which I hoped to reach the lower portion of the reel line, and thas sacrifice, perhaps, only the treble gut and the fly at the extremity. While secking for this, I discovered, about a hundred yards lower down, a little bay, sloping gradually away inland, of comparatively shallow, dead water, as it receded from the stream, quite uninfested ly boughs, boulders, or obstructions of any kind. All this time several fisll were rising in the upper part of the pool, and not a moment was to be lost ; so, having at last fomd a long branch of a seoteh fir, I contrived with its aid to drag out my line-losing only the gut and fly at the end-and quickly putting on the strongest tackle 
and a large hook, I reeommenced operations. It was evidently one day in a hundred. I believe the fish would have risen at any lure, howerer coarse or rudely constructed. At the very first throw I was fast in another, and now I determined to alter my strategy, and to hurry him down stream as quickly as possible, in hopes of reaching the little harbour of dead water before anything untoward should occur, fully prepared, of course, for the hold of the fly giving way, but dreading far more the alternative of the line becoming entangled in the trees which, I was now aware, extended far into the bed of the pool; so raising his head aloove water I allowed him to lash about furiously for a short time, and then, before he had made up his mind in what direetion to bolt, I urged him rapidly down stream, rumning along the hank, but kecping well in front of him, and with a short line forcing him away ly the power of the rod, while the gillie, with a battery of stones which he continued to discharge at intervals, tried to frighten him as mueh as possible from the sulmmerged branches at the side. All this time I saw that fish were still rising aloore me, and I determined, whatever the result might be, to make short work of it, so, reversing my rod, reel upwards, to alter the strain, and again 
"showing him the butt," I fairly dragged him ulong until just opposite the inlet of calm water, and at last steered my prize, now nearly exhuusted, into the weleome haven, where, 'after a few ineffeetual efforts to return to the stream, he was easily clipped; an eighteen-pounder, in prime condition, and as bright as silver. He was hooked through the tongue, and landed in less time thum I have taken to describe the particulars of his capture, and as the numerons plunges in the upper part of the pool showed that the fish still continued in a taking humour-all large salmon, not a grilse among them-I was soon trying for another, and in a few minutes repeating the experiment that had lately proved suecessful, and again at close quarters with a heary fish. Already lad I got him hulf-way down the pool when suddenly the fly lost its hold, the rod became bolt uprighlt and he bade me farewell. The fourth cheounter ended in a capture, and I was equally fortmnte with the fifth, both being firmly hooked, but I lost the sixth very much after the mamer of the first, in trying to force him to the surfuee during the early part of the engagement; he being too wilful or too strong to submit to such severe diseipline: for suddenly turning directly towards me he plunged into the cherent de frise 
close to the bank and quickly dissolved our brief partnership.

The shades of evening were now beginning to fall, and it was time to start for home. I had three good fish, however, to take with me as trophies, and received many congratulations on my success, though I must confess to having felt half ashamed at being compelled to attribute it to tactics less worthy of the noble art than of the deep-sea practice of a professional cod-fisher. 


\section{TYNET BURN AND ITS ICHTHYOLITES.}

"Forthwith the sounds and seas, each ereek and bay With fry innumerable swarm, and shoals Of fish, that with their fins and sbining scales Glide under the green wave . . . . ."

Paradise Lost.

"The tender soil then stiff 'ning by degrees, Sbut from the bounded earth the bounding seas." DRYDEN'S Firgil.

Is one of the long corridors at Gordon Castle comnecting the central or more ancient part of the building with the wings, are placed two small glazed eabinets sinilar to those containing coins or mineralogieal specimens in a public museum. They stand opposite to ench other, immediately under two of the windows that light this passage, and a better situation for displaying their contents could not have been selected. Nevertheless, so closely are the walls on either side studiled with the skulls and antlers of stags grimly looking down on the passer-by as he proceeds to the 
circular gallery at the western extremity-where these trophies of the deer-stalker, reaching all round to the very ceiling, form a perfect Golgotha - that the cabinets and their contents might easily escape his observation. Yet to a student of fossil ichthyology, or I may eren say to a lover of nature like myself, but "skin-deep" in the science, this small collection is most interesting, and doubly so from its having been proeured in the immediate neighbourhood. It was formed by Mr. Arthur Lennox, a talented young geologist, but a few years ago, during a summer visit here, and consists of ealcareous nodules of rarious sizes, which, after having been split longitudinally, exhibit in the centre of each section a more or less perfect representation, in profile, of a fish of the old red sandstone-the formation dereloped in this neighbourhood. Tho nodule, or matrix, contrining each is generally elliptical, that is to say, of an oval form, but depressed instead of being round, and when these are discovered in the shallow stratum or fish-bed, are found lying on their flat sides. They are of a dral colour, while the fossils themselves that are imberded in them appear of a ferruginous Indian red, occasionally tinged with purple, and thus the ontline of the latter is the more distinct from the contrast of its 
deep warm colour to the light tint of the framework in which it is set.

Hugh Miller, the first great explorer of the old red sandstone formation in Scotland, whose charming descriptions are probably unsurpassed in power and eloquence, conjeetures that after the burial of the fish in a soft muddy sediment, the chemieal influence of the deeaying animal matter deposited the lime with which it was eharged, and hence the caleareous nodules in which we find their remains enclosed. Probably the putrefying bodies of the fish might have possessed a similar power of attracting to themselves the oxide of iron from the surrounding mass of ferruginous sand.

Although I had previously seen a few similar specimens in public musemms, yet I confess that they never excited in me more than a temporary interest, or passing feeling of admiration-the rival charms of the huge reptiles of the Oolite or the grigantic mammulia of the Tertiary epoch, although comparatively recent, soon distracting my attention-lout under what different circumstances was I now examining them! The old red sandstone actually surrounded me, its grent antiquity forcing itself more than ever on the imngination. Nothing beneath me, between it and the pre- 
palæozoic non-fossiliferous rocks, but the Silurian deposits with their corals, molluses and crustacea. All subsequent periods unrepresented, though each had its fauna and flora and lasted for millions of years! Palæozoic, Mesozoic, Cainozoic: all passed away without leaving behind a trace of their existence. The coal-seams and compact limestones of the carboniferous age; the coloured sandstones and magnesian limestones of Permia; the salt deposits of the Trias; the reptilian bearing beds of the oolite; the marine fauna of the chalk; the more modern strata of the tertiaries and post-tertiaries! Can we wonder if the human mind is bewildered in endearouring to realize the duration of these accumulated ages? Driven to the very extremity of the abyss of thought, it has sometimes seemed to me that the philosophical sentiment of the Roman poet might often apply to the modern student of the world's history, -

"Quresivit ecelo lueem, ingemuitque repertâ."

Yet it is a matter of strict scientific demonstration that the time which has elapsed sinco the first appearance of man on this earth up to the present moment is absolutely insignificant when compared with the interval between that event and tho period 
when these red sandstone fishes peopled the waters of the Old World.

Perhaps the most wonderful cireumstance connected with these ichthyolites is the preservation of their external form. A good specimen, in fact, represents a picture of the animal itself coloured in light red, Indian red, or occasionally raried with Vandyke brown on a grey baekground, carefully executed, and with many of the detrils far more minutely finisled than if it were an illustration for a modern work on the natural history of fishes. The same peculiarity applies to each in a greater or less degrec, while among the fossil fish of the elnalk and of subsequent formations, instead of this portrait, as it were, of each, the bones alone are usually in $\Omega$ state of preservation, and the ichthyolite is represented by a skeleton. I will endeavour to explain this as familiarly and concisely as I can. All the fish of the old red sandstone epoch were cartilaginous. Those of subsequent formations wero prineipally osseous-or bony-as are with few exeeptions the fish of the present day. The skeleton of the cartilaginons fishes is composel of gristle: mere animal matter without the addition of the calcarcous earth that eonstitutes bone. It was therefore liable to rapid decay, but as if to 
compensate for this, their external covering was like a coat of armour. Their bones in fact were outside, sometimes in the form of broad plates, at others in a beautiful arrangement of elosely-fitting scales, all coated with enamel. This will account for the preservation of the external form. The head, as in osseous fishes, is of bone, but unlike the latter, which is divided into a great number of distinct parts, it generally consisted of a single piece without any joint. It was therefore less liable to deeay, or at least to separation from the body, and yet among the specimens in this colleetion, and in those I subsequently procured myself in the fish-bed of Tynet burn, the slinll was decidedly the least perfect portion of eneh, although in many species it would appear to have been protected by a continuation of the enamelled armour.

But the most striking distinction hetween the cartilaginous and the ordinary osseons fishes, is in the form of the tail. The latter, as yon know, like the salmon, herring, eod, or mackerel, and even the flat turbot or sole, possess a tail composed of two equal parts; set on, as it were, at the end of the vertebral column. Not so among the cartilaginous fishes. With them it is formed on both the upper and lower portion of the spine. In fact, the body, gradually attenuated as it 
approaches the extremity, seems at last to pass through the two portions of the tail, which is invariably much more largely dereloped on the under than on the upper side, so as almost to appear crooked and ill formed. Have you ever seen a shark or a dog-fish? They are modern examples of the cartilaginous series; so is the sturgeon; and in all these the unequally lobed form of tail prevails, although not to such an extent as in these ancient fishes, in some of which indeed the upper portion of the candal fin is even absent altogether.

One specimen in this collection, totally dissimilar as it was from all the others, attracted my attention immediately. The pterichthys_or winged fish. If I had never perused Hugh Miller's pracres, I should hardly have supposed it to be a fish at all. It had more the characters of a crustacen or chelonian animal, to my inexperienced ryes; the body leing covered with plates closely fitting, like those of " lobster or tortoise. Althongrh smaller, it seems to he a more perfect example than that from which Miller-its first discoverer -took his description, the round head heing as distinctly dereloped as the sharp extended wings and pointer tail. The colour, moreover,-as in all these Tynet fossils-was ferruginous, instead 
of being black, like the ichthyolites of Cromarty. The specimen before me measured about four inches and a half in length, and four inches and a quarter from point to point of its wings-exclusive of the matrix. These are supposed by Agassiz not to be organs of locomotion, but a defence against its enemies, on the approach of whom it suddenly extended them, as the pereh erects its dorsal fin, or a stickleback its spines, for a similar purpose. With the exception of the difference in colour to which I have alluded, and a more perfect head, the following brief quotation from Miller will give you a familiar notion of the profile of the pterichthys of Tynet burn. "Imagine the figure of a man rudely drawn in black on a grey ground: the head cut off by the shoulders; the arms spread at full, as in the attitude of swimming; the body rather long than otherwise, and narrowing from the chest downwards; one of the legs cut away at the hip-joint, and the other, as if to preserve the balance, placed directly under the centre of the figure, which it seems to support. Such, at first glance, is the appearance of the fossil."

There are portions of another fish, nearly allied to the pterichthys, in this collection-the coccosteus, or berry-bone. It was covered with an 
armour of bony plates, elosely dotted all over with berry-like protuberances-whence its name. On examining a drawing of the coccosteus restored to its original appenranee, any one acquainted with the fish of the present day would elass it with the rnys. Miller compares it to a boy's kite. These two ichthyolites bear no resemblance to their contemporaries, which indeed, however they mar viry from each other in form and dimensions, and in the character and position of their fins and seales-and therefore deserve the numerons generic and spreific distinetions of A gassiz-yet even to un minseientific eye ure as unmistakally fish as the earp or tencl of modern waters. Unfortunutely, there are no English names ly which they can le recognized, but their elassicnl titlesderived from the Greek-are singularly approprinte, und happily distinguish the more obvious peenliarities of each.

To speak lroadly, they may be elassed in two divisions, corresponding with Cuvier's great orders of Melderpterygii and Acanthopterigii-viz. softfinned fishes, and thorny-finned fishes. The earp and tench are fumiliar modern examples of the first; the perch of the seeond. To begrin with the former. The glyptolepis-carved or senlptured seale-must have been rather a short 
and deep fish. It was covered with large eireular seales, so enormous when compared with the size of the animal, that a specimen not more than half a foot in length, has been known to exhibit scales three-eighths of an inch in diameter, and in another larger fragnentary example, whose entire length would not have exceeded a foot and a lialf, the scales were fully an inch across. These, when examined with the microseope, reveal the most delicate and intricate seulpturingr.

The Osteolepis-or bony scale-is nearly allied. The scales, though less, are yet large in proportion to the size of the animal. The position of the fins is remarkable. The anterior portion of the body seems to be destitute of them, but they crowd together on approaching the tail. The ventral fins are opposite to the space that occurs between the two dorsals, and the caudal-or tail -is unusually developed on the lower side. These organs must have been marvellously constructed. In existing fishes, as Miller remarks, " the membrane is the principal agent in propelling the creature; it strikes arainst the water as the membrane of a bat's wing strikes against the air; but in the fin of the Osteolepis, as in those of many of its contemporaries, we find the condition reversed. The rays were so numerous, and 
lay so thickly side ly side, like the fenthers in the wing of a bird, that they presented to the water a continuous surface of bone, and the membrane only served to support and bind them together."

The Cheirolepis-literally, scaly hand, but as applied to a fish, signifying senly pectoral fin-has a beautiful representative in this collection. The seales, mulike those in the two last-described fossils, are exceedingly small, and seem to run in minute wary diagonal lines from the shoulder backwards, and the fins are similarly clothed. This specimen measmes-exclusive of the matrix -fourteen inches and a laalf in length, and four in diameter.

Of the thorny-finned order-Acanthopteryyiiperhups the most common is the Cheiracenthus, or thorny hand. I have foumd several foreshortened examples myself of this ichthyolite at 'Tynet burn, but its preeise external form is seldom represented in the fossils, as it is gencrally more or less distorted; doubled up), as it were, with its tail almost in its mouth, as if it had expired in agrony, and been petrifed in that uttitude.* Where this oceurs, the nodule is

- I am since indebted to Mr. Simpson, of Tynct, for a remarkably fine sprecimen of The Cheiracanthus, from his own collection, representing the fish in perfect profile. 
simply oval, without any prominences whatever to indicate the position of either extremity. The Cheiracanthus was covered with small enamelled scales, and possessed but one fin on the back, though several below. Their construction was remarkable; each seemed to consist of a single strong spine, to which a thin membrane was attached, so that in fact, as Miller says, "its fins are masts and sails, the spine representing the mast, and the membrane the sail."

In most examples of this little fish the head is very imperfect, doubtless from its haring been composed principally of eartilage, but there is a good speeimen here, only slightly foreslrortened, in which the head is in an unusual state of preservation, the mouth being wide open, and the outline of both jaws distinctly portrayed.

Having now briefly described a few of the more striking of these ichthyolites, I will ask you to accompany me to the spot where, after the lapse of countless centuries, they were at length discovered, and exposed to the light of day. Were I more of a geologrist or less of a sportsman, I might perhaps be ashamed to confess that, if the Spey had during that week been in a more propitious state for angling, the attractions of Salmo salar would have eclipsed those of Cheirolepis or 
Pterichthys, but the water had for some time been provokingly low, and good sport could not be expected until after a change in the weather, which had latterly been exceedingly hot and sultry.

Tynet burn takes its rise in a wild elevated moorland district called White Ash hill, about three miles eastward of Gordon Castle, and flows for about five in a northerly direction parallel to the Spey, entering the sea about two miles to the east of that river. Except in the winter montlis, the quantity of water that finds its way through its chamel would hardly entitle it to highler rank than that of an English brouk, but the rapidity of its strean has enabled it, during comntless centuries, to work its why throngh successive strata of connlomerate and sand-rocks of erery quality and eonsistency. A walk of between two aml three miles across the park and the erreat firwoods-between the tall trmks of which I camndit a glimpse of the bright water of Ortegarbrought me to a brilge crossing the burn, bulow which, at no wrout distance from eneh ether, are two small water-mills. Niar the lowrer of these, the stream is overhung by a perpendicular section of a round hill, throngh which it lans grmlually eaten its way. It harlly deserves the name of at 
preeipice, as the height can scareely exeeed thirty feet. Here, however, about twelve or fifteen feet from the base, are the remains of the fish-bed where the interesting collection of fossils were exhumed by Mr. Lennox, and many specimens in the unrivalled collection of the late Lady Gordon Cumming of Altyre, the rarity and perfeetion of which excited even the admiration of Agassiz.

I had been referred for any practical information I might require to an intelligent observer residing in the immediate neighbourhood,* whom I found most obliging and ready to impart it. He accompanied me to the spot, but held out no hope of a suceessful exploration on my part. In fact, he told me plainly, that "the golden age" was past, that the fish-hed was nearly exhausted, and that the prizes obtained a few years ago could not be equalled ly the results of any future labours. He pointed out to me that the débris which had fallen from the upper surfaee of the eliff-the till, or glncial drift-had obscured, and

* Mr. Simpison, who, when this fish-bed was a virgin mine for explorers, male a valuable rollection of these fossils, the greater part of which be subsequently presented to Sir Roderick Murchison, by whom they were deposited in the Musenm of Practical (reology attached to the Aeological Survey of Great liritain, in Jermyn Strect, London; an institution whose good fortune it was, for many years, to possess as its chief "The Emperor of Siluria." 
indeed choked up the residue of the fish-hed, and until this was remored eren partial success was out of the question. A few seasons of heary rain, hard frost, and subsequent thaws had loosened the consistency of the upper stratum of mould and gravel, portions of which were arrested in their descent, and patehes of broom and gorse had consequently taken root half-way down, netually appearing to grow out of a hard bed of conglomerate, while each succeding year added to the ruins. Great was my disappointment, thongh I derived some consolation from diseovering, at the base of the cliff, several small nodules, and some of eren larer dimensions in the bed of the stream, under water, for which I continued to wade persereringly during the remainder of the afternoon, and earried home the greater portion of them in my fish-hag.

Before dark that evening I had explored their contents. Although by no means sangruine on the sulject, I land rentured to expeet licter luck, but my hands were at last weary of wielding hommer and ehisel when my labour was only rewarded oceasionally by a mere ferruginous spot in the centre of the nolule, or a few seales or spines, or at lest, by the tail or some framment of an ichthyolite. By far the greater number con- 
tained nothing at all. Success was evidently out of the question until I could get at the fish-bed itself.

With the assistance of two able-bodicd quarrymen, who worked hard for a eouple of days, a considerable portion of the accumulated rublish and several dangerous projecting masses overhead were finally removed, and this part of the cliff at length presented a different appearanee. 'The base near the stream was composel of several layers of hard sandstone, perfectly distinct from each other, yet varying but little in eolour or consistency; alternating with these were ocersional seams of pudling-stone or conglomerate, all, less or more, of a ferruginous or deep-red tint, above which, ahout fifteen feet from the burn, a drab-colonred layer-nppurently marl or indurated chy-had been exposed, studded here and there with nodules of the same appearnuce ats those I had already found in the stream, but so firmly imbelded in the shale that it required the use of a small pickaxe, especially male for the purpose, to remove them without injury. This was the fuce of the fish-hed, or rathrer, all that remained of it, which I was enalled to reach by a narrow sloping terrace, or shelf, immeliately underneath. The diameter of the marly stratum 
and the size of its nodules had diminished considerably since its first liscovery, the centre of the bed, the tomb of the largest ichthyolites, having long since been despoiled of its treasures. Enough, however, remained to encourage a trial. Need I say with what energy I commenced operations, or how lopefully I continued to work until I lual extracted nearly a hundred nodules, few of which, however, contained anything worth preserving. Gradually, my zeal was beginning to flag, when sudilenly one of a form rather mussual, und of considerable size, attructed my attention, as it stuck half-way out of the marl. Instead of being oval, the portion that protruded was rather oblong, but the angrles were unequal. In fivet, when removed, it represented roughly, but correctly, the outline of a fish, the obtuse (nul of the surcopluagus enclosing the tuil, the opposito extremity being romeded, while even the dorsal and rentral fins lund their corresponding projections. With what breatleless suspense did I apply the hummer: A verticnl blow som sepurated it into two parts. and the chisel gradually revoaled to my deligrhten cyes, first the unterior lanlf, then the remuining portion of a benutiful Ostonlepis. 'The lones of the head, which are generally foumd to he dislocated, were nenrly in their proper places, while 
the entire body was covered with scales like a coat of armour, and as brilliant as mother-of-pearl. In fact, although of moderate dimensions, it was fresher and more distinct than any specimen I had hitherto seen.

Several subsequent visits have I since paid to the same spot, and although I have frequently succeeded in securing small specimens of Cheiracanthus, Cheirolepis, and Diplacanthus, and even fragmentary plates of Coccostens and Pterichthys, yet on none of these occasions have $I$ felt such a thrilling interest as when I discovered my first perfect Osteolepis in the fish-bed of Tynet burn.*

- The fish-beds of Clune and Lethenbar lie about thirty miles to the westward, near the Findhorn river. It is related by Mr. Duff, in his sketeh of the Geology of Moray, that the nodules in that lacality being composed of erystallized fibro-earbonate of lime, and therefore of the purest quality for eement or for agrieultural purposes, were for several years burned into lime shells, and many were the valuable specimens of fossil fishes that were sacrificed in the operation. It is told by the people in the neighlourhood that the late proprietor, suspecting that the nodules contained lime, sent specimens of them to Blinhurgh to be analyzed, and received them back with the assuranee that they were of pure lime and adapted for useful purposes ; but the included ichthyolites were not noticed, and the work of destruetion went on till Dr. Mal. eolmson deteeted them and informed the scientific world of their great interest. 


\section{ALT DERG.}

\footnotetext{
"Quorlque fuit campus, vallem decursus aquarum

Fecit ; et eluvie mons est deductus in requor."
}

OrIn.

ONE of the most remarkable spots amidst the peculiar scenery of the sandstone hills near Gordon Castle is . Alt Deror-or the red burn-although the latter title can convey no idea of its extraordinary configuration or peculiarities, for the hed of the so-called "burn" is now perfectly dry during summer and antumn, althongh it is doultesess to the long-continued erosive action of ruming water durinir past eenturies, aided ly the alternate influence of frost, rain, and molted ice and snow, that the deep excavation of the main gren is to be attributed, as well as of those tributary fissures that run in on either side, through which in hygone ages a cumbrous burden of rocks, munt, stones, and gravel was discharged into the bed of 
the Spey, and finally swept down by successive spates into the ocean itself.

I have already referred to the striking aspect of this gorge as it presents itself to a spectator from the opposite or left bank of the river, the previous eourse of its tributaries through the pinecovered hills being marked by zigzag lines of com. paratively diminutive proportions, gradually increasing in depth and extent as they approach its termination, where, rising from its steep sides clothed with lineh and firs, numerons tall, cylindrical cones of eonglomerate shoot up from amidst the foliage of the trees, like gigantic sentinels keeping watch and ward over the entrance of the glen.

Alt Derg is about a comple of miles from Fochabers, from whenee the road lies along the higher grounds on the right, looking down on the haughs and slopes above the (ireenbank pool and the Cruive dylie, after which a path winds alont for a little way among undulating ground, and it is not until you arrive at the very marenin of the ravine that its immediate ricinity is indicated by any feature of the surrounling secrery. The bed beneath appears to be thickly strewed, as far as the eye ean rench on either side, with smowth boulders and stones of every imaginable colour; 
and looking down, as I did, for the first time, on this varicarated pavement during a sudden hurst of sunshine after a heary shower of rain, the whole scene was almost enough to enable me to realize, for a moment, the fabulous but fascinating description of Sindbad's valley of precions stones in "The Arabian Nirhts." A narrow track, winding down along the steep side, leals to the bottom, and on arriving there, the peculiar character of the scenery becomes even more striking. It is impossible to resist the conviction that you are walking over the dry bed of what must lave been at some former-and, ceologrieally spenking, not very distant-rech, a powerful torrent. All the loose stones muler your feet are romided and water-worn, and although the sides of tho main glen are less precipitous than those of the lesser fissures that run in diagonally, yet the arosive action of the water ean be traced where the lower and more indurated portions present ocensionally slarp perpendicular sections, above which the matural woods of spruee and hareh seem to eling witle diffienlty, and to spront out in almost impossible places, while every now and then a forruginous peak, like a great sugar-lonf, or two in juxtaposition, like Sinmese twins, shoot up from the midst, in striking contrast to the sur- 
rounding verdure. These eminences were doubtless originally cut by water out of a conglomerate composed chiefly of materials from the underlying Silurian beds and forming part of the middle division of the old red sandstone formation, and would appear to owe their present configuration to atmospheric influences. Successive frosts and rains gradually decompose the softer material, which is slowly washed away, and the same process, continued annually, leaves at last nothing but the denuded and comparatively hard portion adhering to the central baclibone, as it were, of these elevated cones and turrets.

Following the eccentric course of the burn towards the hills, and trudging laboriously through the loose boulders under your feet, new scenes, though of limited extent, are continually disclosed, as each in succession vanishes from your view; while, with the bright sunshine falling upon many a little promontory of funtastic form projecting into the foreground and lighting up the recesses of the larch and fir-groves above-the opposite banks loing at the same time reiled in dark shadow-you feel that, at every turn, an artist would gladly linger, for the sake of adding a charming rignette to the pages of his sketchbook. 
Some of the lesser ravines which rum in on either side present a totally different appearmee, although they must formerly have served as tributary watercourses to the main stream. One of these, near the mouth of the gorge, which I earefully explored, was not more than eight or ten feet wide, and became still more eontracted as I clambered up its irregular ascent, over débris of large stones and sharp, angular blocks that lay in the very centre of its bed. The steep sides of this cleft conld not have been less than thirty feet high, and the escarpment on either side was quite perpendicular, reminling me of one of those nurrow streets of lofty houses, in certuin old fortified German towns, that debonche at the bottom of a steep hill into the principal thoroughfure. The walls of the fissure to a great height exlibited a mass of conglomerate, lut above this I pereedied that the upper portion of the cliff was composed of the till, or glacial drift, overluying the more meient formation, of a somewhat lighter colour, but nearly resembling it in character and consistence. The depth of these beds varied remarkably. Immediately over my head the deposit was of unusual thickness, withont any traces of stratification, und containing angular stones, rocks, and 
pebbles, indiscriminately scattered through the whole. One of considerable size at my feet appeared to have but recently fallen, a portion of the clay in which it was imbedled still adhering to it, and on looking up to diseover the place from which it must have dropped, I perceived another of nearly equal dimensions projecting at right angles from the eliff, and suspended, like the sword of Damocles, over my head. So slight a hold did it appear to have in the loose boulder clay, that the report of a gun, discharged from the bottom of the narrow chasm where I stood, would probably have caused it to fall immediately. All the rocks in this part of Scotland are more or less covered by this deposit, composed of débris carried down from the distant mountains by the moving masses of land ice that annually swept over the country during the glacial epoch. At a subsequent period the rradual formation of watercourses followed. These, excavating their ehannels, slowly but surely, during countless centuries, have eaten their way alike througl the superineumbent drift and the more indurated mass of eonglomerate beneath. The professed geologist, indeed, ean discover many other places in this district, and on the banks of the Spey itself, cal- 
culated to illustrate these interesting fitets. lunt the lover of nature will not appreceiate seientitic. truth the less from its being associnted with such nowed and quant seenery as is exhibited in the. erorere of Alt Derg and its tributary ravines.
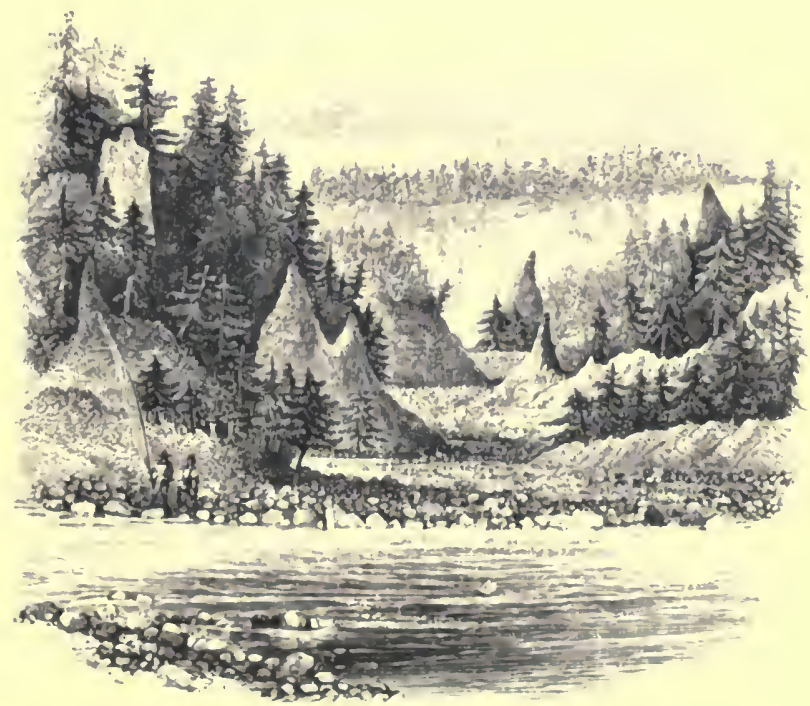


\section{B I R I) S.}

"The Fagles are gone!"

Troilus and Crosside.

Is the heart of the great pine-woods that stretch over the hills, north-east of the park, lnt below the gorges that wind their way upwards through the red sandstone slopes, lie two or three little lochs much frequented by wild-ducks and other waterfowl during the antmmal and winter months. So completely are they excluded from view by the surroumding forest that a stramerer might fail to discover their whereabonts, even after a prolonged scareh, and the first intimation of his suecess would probably be the whirring semed of a party of duelis or teal over his head, alumed lyy the eracking of dead sticks under his feet, or. if the weather happened to be ealn and hrighlit, by the reflection of the sumshine from the surfitere of the water piereiner through the tall stems of the fir-trees. 
The most beantifnl and least elevated of these secluded tarns is called Ortegarr-its old Gaelic title. The first time I risited it was during a stormy day, with three or four other gumners, for the express purpose of getting a shot at the wildfowl, rough weather proving favourable for the sport, as they then quit the tempestnous estuary at the mouth of the river and the exposed lagoons along its sides, and seek the comparatively sheltered waters of this loch. The continuons roar, too, of the wind through the pine-trees is all in farour of sport, as the approach of the shooters stenlthily crawling towards the margin, from opposite directions, is less likely to be revealed to the watchful birds by the snapping of dead branches or any other sound, and on this occasion ench of us succeeded in reaching his own especial little screen of boughs, constructed near the lanks, hefore any of them were alarmed. Presently a whirring of wings and a loud quacking, followed by two or three shots from the opposite side, told that we were discovered, and a brisk fusillade commenced. Mallards, ducks, and tral flew orer our hends within easy distance, and many fell at the first rolley. Then circling round several times in detached parties, they presented more diffienlt shots. but by our remaining in concealment, some of the 
less timid descended again towards the water, either singly or in reduced numbers, and passing within fatal distance of a sereen, would drop to rise no more, until by degrees even the last stragglers vanished and all was over for that day.

A year or two afterwards, during a long spell of sultry, cloudless weather in the early part of September, I was again wandering through these woods, with no companion but my spy-glass, in hopes of meeting with my old friends the erossbills, Loxia curvirostra, or perhaps the still rarer crested titmouse, Parus cristatus, which I have never succeeded in detecting, although I knew that the species had been observed about thirty miles ligher up the Spey, near Grantown, as well as still further south in the pass of Killickrankie. After a fruitless search of some hours I found myself close to Ortegarr, and-on this occasion with the most friendly intentions towards the birds that frequented it-I commeneed erawling through the heather in that direction as slowly and cantiously as possible. I was well rewarded for ny tronble, and suceecded at last in reaching a slightly elevated mound, but a few yards from the edge, where, through a vista hetween the fir-trees that fringed the bank, I commanded a view of the greater part of the little sheet of water. It was 
a heautiful sight. Within twenty yards of me were a roebuck and a rae browsing leisurely on the suceulent grasses near the margin. Farther on the left lay a little swampy island densely chothed with wild iris, bulrushes, and other aquatic plants of varions colours, and on the intermediate water were several mallarls, ducks, teal, coots, moor-hens, and little grebes swimming about and oceasionally disappearing anong the rank herbage or cmerging from its recesses; while knee-deep at the very edge stood a stately heron, motionless as a stutue, intently watching for his prey. This part of the pool was slightly overshadowed by the reflection of the tall trees behind, but farther off the bright sun fell upon the water, lighting np ut the sume time the interior of the spruce firs and lareh groves that clothed the more distant banks. In the very centre of the loch a cormormit was fishing by himself, incessantly diving and remaining a long time benenth, lout rurely suceceding in capturing anythiner but rery small eels. Every now and then a shadow, like a little clond, would puss overhend, and a heron would sail through the still nir or thap heavily along the surface of the water until he took up his position among the shallows in the distanee. After watching this peaceful 
scene for some time, I perceived that the roedeer were becoming gradually aware of my presence, having evidently "got my wind." First they raised their heads and stared almost ineredulously at my place of concealment, as if doubting the possibility of an enemy having appronehed so near them without discovery. Then suddenly taking alarm, they trotted off rapidly into the depth of the forest. Next the heron rose from the extremity of the little island where he had so long remained motionless, and, extending his legs behind him, flew lazily to the other end of the tarn, rousing the cormorant on his way, who with a more rapid flight quitted the scene altogether and disappeared over the trees in the direction of the river. In the meantime many of the wild-ducks and teal, having taken wing immediately after the departure of their friend and sentinel, the heron, collected together in small parties and continued to circle over my head, ever increasing their distance, but apparently unwilling to quit their furourite hannts, until at last, finding they had no just eause for disquictude, they crarlually approached the water again, and finally settled down at the further extremity of the loch.

I rejoice to say that the herons are strictly pre- 


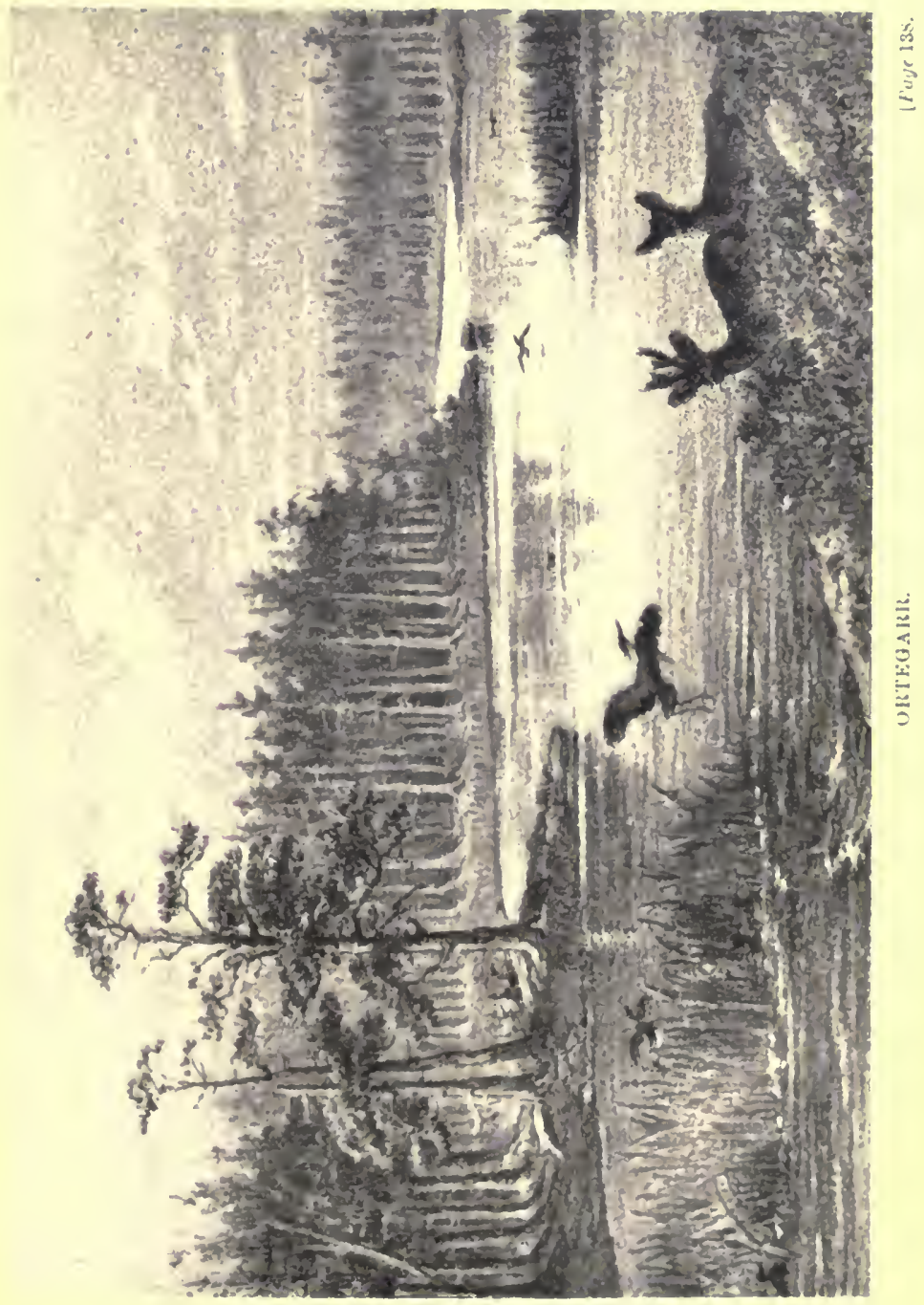



served und their numbers consequently inereasing. Their nests ure not visible from the banks of the tarn, but I found sereral among the Seoteh firs at a little distance. Would that the protection here ufforded to these interesting birds were extended to them generally in the north, as well as to the larger and nobler members of the Faleonide, which have now become exceedingly rure, and appear doomed to total extinction.

1) uring my many visits to this purt of Scotland, I never hat the good fortume to see the golden or sea eagle on the wing, along the lower course of the spey or in the deer-forests of Glenfidilich and Blackwater. It is true thut there ure no eyries of either species in this district, and it is in such situations-as the inland predipices of the (iram. pians, and the sen-elifts of the northern sud western consts-thut the principal destruction takes place. The excessive preservation of enrouse and the value of the eargs of the golden angle. Aquila chrysaetos, to collectors, have principully. tended to rednce the numbers of that numbifient birl, while the depredations of the sou raghe. IIaliretus albicilla, among yomug lambs. with which he ocensionally varies his tish diet. have doomed him to persecution hy the shepherds ats 
well as gamekeepers; but in the eyes of the experienced forester the former species, at any rate, appears in a different light. He knows him to be a valuable ally to the deer-stalker as a check upon the inordinate inerease of the prolific blue hare, Lepus variabilis, which indeed constitutes his faromrite prey. Every stalker ean eall to mind how many a goodly stag has escaped from his rifle, just, perhaps, at the very moment when success seemed almost certain, through one of these animals suddenly starting up in front of him, rumning towards the nearest hinds and effectually alarming those watchful sentinels, before the desired range was obtained. During the autumn of 1862 I passed a week or ten days in the forest of Bramar, in the heart of the Grampians, and besides good sport, deer-stalking, I had the additional pleasure almost every day of observing the golden eagle in his native hannts. I well remember my first view of the nolle lird in this forest. He was souring at a great liejght, every now and then arresting his career and hovering in the air like a kestre], apparently watching some victim in the fier henther below, and attended by a rabble rout of lesser hirds, which, even allowing for distunce, I could hardly believe to be larger than jackdaws. On examining them 
through my spy-glass, I pereeived that they were looded erows, who kept up their vain but pertinacious annoymee as long as he remained in riew. My surprise, however, was not greater than my delight when the forester pointed out the royal nest on an old Scoteh fir-tree, which, with severnl others, at some distance from each other, studded the side of a hill near the base of Ben y Bourd. Every onithologieal muthority that I was acquainted with had invariably assigned lofty inland crags and precipices to the golden eagle as the situation of his eyrie; und, indeed, the high 'liff' behind Corriemulzie, where he used to brecd, owes its present title to the circumstance, lont this was the only instance I had ever known of the nest being constrncted in a tree. Such is the result of preservation; or, in other words, the absence of persecntion, for the services of the agrle lave been long appreeiated and the lirels themselves protected ly the proprietor of the forest, so that it would really appear as if the establishment of confidence had rendered them loss mxious to select an inaccessible position for their errie. 'T'he' nest itself was not above twenty feet from the ground, built on one of the larger horizontal branches extending from the nnked trunk; smd. 
with the assistance of a gillie, I succeeded in climbing to it and examined its structure and contents. The enormons fabric was about eight feet wide. Some of the external sticks of which it was composed were nearly as thick as my wrist. their size gradually diminishing towards the centre, which was lined with birch twigs and heather. In the interior was an addled egg. where it had remained since the previous spring, white, like that of the sea eagle, and without any of the ferruginous or reddish colour that is more characteristic of the golden eagle'salthough this pale rariety is oceasionally found eren among prolific eggs of the latter species. Besides this, the nest contained sereral large wing and tail-feathers of the owner, a quantity of down - from the roung birds - the foot of a blue hare, the wing and leg of a ptarmigan, and the halfderoured body of a recently killed looded crow. It was erident that the parents still used it as a larder, which was satisfactorily explained, a few days afterwards, on ms perceiving two immature golden eagles, whose ringed tails were distinctly visible through my spy-glass, flying about the tree and alighting occasionally on the ground, evidently expecting to be fed by their parents, neither of 
whom, however, appeared on that occasion, although repeatedly summoned by the loud screams of the younger birds.

For several years the golden eagle has estal,. lished its eyrie on a Scotch fir in this forest. A stout bough, with strong lateral branches, is selected in the first instance, and the nest, such as I have described, construeted on the platform. In the following spring the fabric, even when apparently uninjured ly the winter storms, is added to, or "put out" as the furesters call it. The same process is repeated annually, until at length the overburdened bough gives way and snaps off, carrying with it to the rround the aceumulated mass of sticks, brushwool, and heather, and next year a new tree is chosen for the eyrie, sometimes at a ireat distance from that which had been previously oceupied.

I may here mention, en passent, that while at Bremar I had the first, and only opportunity during $m y$ life, of seeing the goshawk-1stur palumbarius-in a state of nature. A female of this species, in adult plumage, passed quite close to me, on two oceasions, while returning in the evening from deer-stalking, near the top of Glenderry. The short wings, loug tail, and trans. versely barred breast were of course conspicuous, 
and once I could even perceive the yellow iris. Altogether the bird was a gigantic representative of the sparrowhawk-Aceipiter nisus.

In the neighbourhood of Gordon Castle, along the lower district of Spey, or in the deer-forests of Glenfiddich or Blackwater, I never observed either the golden or the sea eagle, but I have occasionally seen the osprey, I'andion halieetus, circling overhead, and following the course of the river, although at a great height from the water. A bird of this species frequently takes up his quarters at Glenfiddich during the antmmn, where I rejoice to say he is now safe from persecution, and where his depredations are cxclusively confined to the small trout that ahound in the mountain tributaries of the Spey. The Rer. Dr. Gordon, in his notes of the fauna of Moray, published some years ago in The Yoologfist, says, that the osprey used to huild in the ruins of Lochaneilan, Badenoch, and that a nest has also been found at Almore, in Glemmore. 'L'he species is, however, hecoming rarer every day. Any one who has lual the good fortune to witness its arraceful flight and marvellons mole of fishing, will regret its appronchingr disappenance, as an indigenous bird, from the British fuma; and the same remark applies to the kite-miscalled Milvus 
vulyaris. Truly this specifie title must have been upplied to it in very different times from the present. I luve never seen one on the wing in this part of Scotland. It lats beeome in fact a rarissima aris, even in those districts where it used to be abundant; the result of constant persecution. I may, perhimps, be allowed here to quote from a former little work of my own, a list of "vermin" destroyed on the Glengury property, furnished to me ly a friend, who was himself the lessee of the shootings ut the time-from 1837 to 1840 - mnd by whose orders the slaughiter was enrried into eflect. If we remember that this sistem has been carried out generally for muny past yeurs throughout Scothand, with a view to the preservation of grouse, the excessive rarity of the larger species of Fiblemide nt the present day ean no longer be a muter of surprise. Numerous keepers were employed in this wholesale massacre, who recived not only liberal wages, but extra rewurls, varying from 103 to 15 , nceording to their suceess in the work of extermination. The ornithologrist will be "little puzzled ly the titles given to some of thes liaptores, hut the numes and eprithets applied to the creater number of them are, nevortheless, musually clear and appropriate, and will lear. - "Game Birds and Wild Fowl. Their Friends and their Foes," 
no doubt in his mind as to the identity of some of the rarer victims. On this occasion I have omitted the quadrupeds, who figured equally in this black list:-

27 White-tailed Eagles.

15 Golden eagles.

18 Ospreys, or fishing eagles.

98 Blue hawks, or peregrine falcons.

275 Kites, commonly called salmon-tailed gledes.

5 Marsh harriers, or yellow. legged hawks.

63 Gosliawks.

7 Orange-legged falcons.

11 Hobby hawks.

285 Common buzzards.

371 Rough-legged buzzards.

3 Honey buzzards.
462 Kestrels, or red hawks.

78 Merlin hawks.

9 Ash-coloured hawks, or large blue-tailed ditto.

$83 \mathrm{Hen}$ harriers, or ring-tailed lawks.

6 Jerfalcon, toe-featliered hawks (?).

1431 Hooled or carrion crows.

475 Ravens.

35 Horned owIs.

71 Common fern owls. *

3 Goldeu owls. +

8 Magpies.

But, since the ravages of the grouse disease, it may fairly be questioned whether the prevalence of that mysterious compluint may not be chicfly attributable to the removal of the natural checks on the inordinate inerease of the species, fostered by so many contrivances, and notubly by the destruction of those birds of prey whose furomite food they constituted. 'The weak and sickly, or superannuated members of a pack, were of eourse captured

* Probably the short-eares owl (Otus brachyotos). Surely not the insectivorous night-jar!

† The white or barn owl, comparatively rare in Scotland. 
with facility, while the more vigorous and active eserped. Thus a sound stock survived for breeding, and the result was a healtly progeny, free from the admixture of a degenerate race of more numerous descendants, naturally liable to ejidemic disease and premature decay. Every old grouse-shooter can eall to mind how often in former times, when the peregrine was of comparatively eommon oceurrence, he has experiened the vexation of seeing some of his wounded hirds enrried off by that powerful fuleon, evidently solected as more casy victims than the re'st of the pack. No predacious birl apuals this species in courage and rapidity of flight. We may conclude, then, that sickly or otherwise delilitated grouse wonld generally fall to the shure of the ben harrier, Circus cyaneus, formerly a eommon speces, and still the lenst rure of the larper Falcomidte; of the marsh harrier. Circus aruginosus; of the common buzzard, Butero rulgaris; and of the kite, Milinus regulis.

When fishing in the spey near beat of hrien, ahout five mile above Fochuleers, I have frequently seen the perenrine faleen, Faleo peregrinus. Tha great hill of Ben Aigen has two larere fissures on the northern and north-western sides, which can be distinetly seen from here, in the stere esearp- 
ments of which this falcon breeds, although the nest is occasionally robbed of eggs or young.

Of indigenous owls, the long-eared-Otus vulgaris - and the tawny-Syrnium aluco-are the most common. The hootings of the latter may still be heard every evening in the park, although the species has certainly decreased in number during the last few years. Indeed it is only wonderful how it survives. On securing a rat or young rabbit, the instinct of this owl-as well as of many other rapacious birds-prompts it to fly at once with its prey to a leafless stump or pollarded tree, on the flat summit of which it loves to feast uninterruptedly. Arailing themselres of this habit, the wily licepers construct the pole-trap-simply a board nailed horizontally on the top of a post, ten or twelve feet from the ground. No bait or lure is necessary : a naked gin is placed on the flat piece of wood alove: the unfortunate owl flies mnesitatingly to the nearest and is inevitally cuptured.

Among the numerous victims that adorn (?) a conspicnous wall near the head leeper's residence, the tawny owl seems to predominate. His companions in diserace, however, are sufficiently numerous, principally kestrels, sparrow-lawks, merlins, and a few hobbies, for the larger species 
of Fulconide have become so rare as seldom to find a place in this Golgotha.*

All the British members of the swallow family, IFirundinide, abound in the lower portion of Moray and Banffshire during the summer. The swift departs in July, but the rest remain far into the antumn. The chimmey swallow and house martin are commonest. The sund martin, Iirumdo riperia, is but partially distributed. The numerous cliffs and precipiess along the bauks of the Spey, and the sides of the dry watercourses and grorges intersecting the neighbouring lills, all in the red sandstone systent, would appear at first sight to offer forvoumble situations for settlements of these hirds during the breeding season, but such is not the ease. I was mueh struck with a singular proof of this while examining the steep perpendicular side of a

- If these desultory remarks on some of the surviving Fal. conider should induce the ornithologieal rewler to desire a more general acquaintance with the hirls of this district-inligenous as well as inigratory-he will find ample and trustworthy information on the subject in a work eompilet from the journals and leeters of the late lamenterl Charles St. John, and published sinem his decease, entitled "Natural History and Sinrt in Moray." I lew very rare visitors have siuce heen met with, such as l'allas's three. toed sand grouse, syrrluptes paradorus; the nutracker. Vinci. frage coryesuturtes; the roller, Corarias gurmula : and sevemal examples of the greater spotted woolpecker, Pirus maji, : whome occurrence will he recorded at the end of this chidjter. 
quarry near the river. A few sand martins flying overhead induced me to believe that I should find some excavations of this species in the face of the prevalent strata. All these, however different in texture and composition-from the loose half solidified conglomerates and harder deposits, to the bands of fine friable sandstone and indurated layers of the same substance with which they alternated-were more or less coloured by red oxide of iron, and not one of them was piereed by the martin, but nearer the summit of the eliff a horizontal shallow belt of yellow sandstonea comparatively recent formation-extended for several yards, exhibiting a single row of perforations nearly equidistant from each other, like the portholes of a gun-brig.

Of the many indigenous birds unjustly proseribed and grudually diminishing in number, the water ouzel, or dipper, Cinclus aquaticus, appears to me to be the most flagrant eximple, and I gladly avail myself of this opportunity of recording my belicf that he is not only an injured innocent lut an ill-used benefactor. For ages he has been condemned as a supposed devourer of trout and salmon spawn, but I am eonvineed that such a charge has no more foundation in truth than the once popular fables of cows and goats 
being milked ly the hedgehog and the nightejur. I have land mony olportmities of olserving this bird nurowly, more frequently in lrelund und Wales than even in seothund, and I may adkthough not withont a slight pung of remorsothat in the stemachs of the muny specinens I lnve shot and disseeted. eren when in the commission of the smpposed net of lareeny, I nexere could deteet any pertion of the spuwn of either trout or sulnom. Let us for a moment witelh the

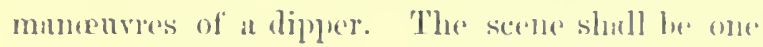
of his forourite hamnts, the recky lomks of " momituin born, or the gravelly shallows of $n$ larerer strenm. Perhaps you are quietly semterl among the henthere alove, resting during the hent

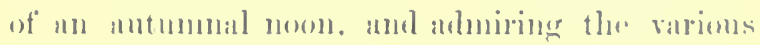
colours of the mosses, lichens. und lyoperdin thut clothe the norrerin. Sou are struek ly the loneliness of the scene. Nothing living alpperars to mimate it. Suldenly at water mozel

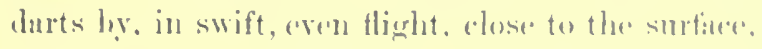
ane uligrlits on a flat stene in the midule of the

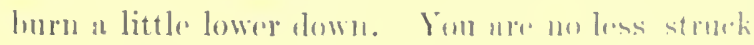
by his beanty-hiss sonw-whito herest rontmeting with his otherwise dark flumign- than with his attitudes and performuners: nomldiner his head and jerking his shent tail after the manner of a 
wren, and then suddenly plungring into the stream, where you lose sight of him until he reappears ou the surface in a few seconds a little lower down. and perhaps resumes his position on the same rock, or flies to a stone nearer the bank. You have probably read or heard that he can dive witl facility and walk about at his ease on the rravelly bottom. Now is your time to wateh his actions under water and to judge for yourself. Tou rum quickly towirds the spot, but are eareful to check your speed and lie down before you reach it lest you shonld alarm him prematurely. Ayain he rises from the burn, rests for a moment on a stone, and soon disappens once more bencath the surface. Now you repeat your former nuncenver and reach the marerin in time, ahove thr very spot where he has just plunged into the cham shallow stream, and, looking down, you distinctly. see lim strugrgliner with violent afforts to reach the bottom, towards which his head and nerels aro alreuly protruder : working his wings all the time with considerable axortion and apporent difficnlty. quite molike the comparatively farcile movements of" a coot or comolnut or any hird of similar specific gravity whon in tho anet of diving. Now he secmes to chuteh thr romm polbles for at fow seconds and to be amployed in extracting some- 
thing from among them, but the ripple of the current prevents more accurate observation on your part. At last he comes once more to the surface, and, alarmed at your presence, darts along the burn. His flight is as even as that of a purtridge, and he presents an easy shot. To satisfy yourself of his guilt or innocence, youreluctantly-pull the trigger and he floats lifeless on the stream. Now for the trial. You carefully dissect his crop and stomach and examine their contents, and you discover several larve of phryganese and ephemere, minute beetles, and other aquatic insects, and several very small freshwater sunils, ${ }^{*}$ but you search in vain for the ora of trout. Such an incident as I have just hurriedly described hus occurred to myself repentedly, and the result of my observations induees me to believe not only in the harmlessuess of this interesting little bird-whose spring solug, ly the way, is excedingly melodious, but that instent of heing a destroyer of fish-spawn, he renlly assists in its preservation, by acting us a check on the increase of various predacions water-hertles, and other aquatic insects whose ravenous grulsis or lerre furnish his farourite food. His persecutors

- I have found sandhoppers, Talitris lucusta, in the stomaclis of some dipyers killed on the bauks of large rivers. 
are therefore, in my humble opinion, amenable to the double charge of injustice and ingratitude.

From the Moray Firth and the sheltered bays of Dornoch and Cromarty on the opposite side, vast numbers of wild-fowl pass over the Spey during the latter part of the autumn on their way to a more genial climate. About the cnd of October, if the weather happened to be severe, I have seen licrds of wild swans and flocks of greese and marine ducks of rarious species flying overhead, gencrally in a south-westerly direction, towards Loch Ness. The temperature of this region, however, although so far north, is comparatively mild in early winter, heary snow-storms seldom taking place until January.

Some very rare visitors have occurred during late years. The greater spotted woodpecker, Picus major, had certainly been met with occasionally either singly or in pairs-as at Castle Grant and near Inverness-lont duringr the autumn of 1868 the species appeared in unusual numbers on both sides of the Moray Firth, showing that a flock of "African woodpeckers" - as they were there ealled-must have visited the nortl of Seotland. Mr. Yarrell notices that "although this bird occurs in all the southern and midland counties of England, it lecomes rure on proceeding north- 
wards. Nevertheless," he adds, "scarcely a year passes without some being ohtained in Northum. berland during Octoher and November. 'This induces me to suppose that they are migratery in some of the more northern parts of Europe, perhaps in Norway and Sweden. They arrive about the same time as the woodecek and other equatorial migrants. . . . . Mr. Selhy says thut he has seen it in Scotland on the banks of the river Spey, and amid the wild seenery of the Dee."* In sussex, this bird is a spring urrivul.

When visiting the Eilgin Museum, in the sume year, with the Rev. Dr. Gordon, he pointed ont to me a loney linzzard which had been recently killed at Pluscarden, and a few daỵs afterwurils, being nt Inverness, I had the opportunity of examininer, in the Hesh, at Mr. MeLcay's, u leantiful specimen of the roller, Coracias garrulu, which had heen shot by a unmekeeper of the name of Nicholson, in the Oak Wood, and ahout ten days previonsly un example of the same rare visitor lad been killed at Dornoch hy Mr. lierr Fraser. This species is said to lave beren met with in Orkney. It would uppear to have a wile greneraplical range, and yet to be very partially distri. buted. It is very rare in Fingland, of common

- Yarkellos Brilish Birds 
occurrence at Malta, during the spring and autumnal migration from Africa, scarce in France, unknown in Holland, but occasionally a wanderer to Sweden and Denmark.

That still more uncommon British visitor the nutcracker, Nucifraga caryocatactes, was killed about the same time at Invergarry. 'This species is a native of the pine forests of Russin and Norway, and is also found in Switzerland and among the Austrian Alps.

But the greatest ornithological curiosity that has ever been met with in this part of Scotland is the three-toed sand grouse, Syrrhaptes paradoxus, a specimen of which was shot by the Duke of Riehmond, on the $23 \mathrm{rd}$ of October, 1863, out of a flock of seven or eight which he flushed while partridge-shooting on the banks of the Spey, between Gordon Castle and the month of the river. They rose from the shingle and at once attracted his attention by their rupid, swallowlike flight and unusual ery, and flew directly across the river.* 'This lird is a native of the steppes of Tartary, and until lately was muknown even as an accidental risitor to any part of Europe. The genus consists of a single species, and the

- Dr. Gordon informs ine that a specimen was killed at Lossiemouth, and another at Dornoch about the same time. 
first instance of its occurrence in these islands was in July, 1859, when an individual shot by a labourer on Portreuddyn Farm, at the north and of Cardigan Bay, found its way to the Derby Museum at Liverpool.* In 1863, there occurred a regular irruption of these birds across Europe to the shores of England, and several specimens were obtained, principally in the eastern counties. since which period the migration has apparently ceased, and the sand grouse is once agrain a rerissima aris, more prized than ever by collectors, haviner now established its title to he considered " British bird. In un exhaustive article communicated to "The Ilis," Professor Alfierl Nowton has not only recoried the particulars of what he "ptly terms "this Turtar invasion," illustrated lỵ a sketeh map, but given us an ample biourruplyy of the species, equally remarkuble for scicutitic research und lahorions investiontion, as woll as for the folicitons style which churnctorizes whatever fulls from the pen of that distineruished ornithologist.

"Mr. T. J. Moore in "The Ibis," lst serius. Vol. II. 


\title{
CAPTURE OF A LEVIATHAN.
}

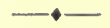

"Now hope exults the fisher's beating heart, Now he turns pale and fears his dubious art: He views the tumbling fish with longing eyes, While the line stretehes with th' unwieldy prize, Each motion humours with his stealy lianels, And one slight hair the mighty bulk commands."
\end{abstract}

GAY.

IT was the 14th of October, 1868, the last day but one of the season. The sport during the previous fortnight had been unusnully good. Frequent rains towards the close of Septemlier had succeeded a long period of dronght, and after the clearing of the water many heary fish-from twenty-five to thirty-three pounds-lad been taken, while a few of still greater weight had been olserved "travellingr" up stream. My destination on that morning was to a part of the river about five miles alowe hrikge, comprising three or four pools beyond Orton, and as the erenings were now lecrinning to close in rapidly, 
aud I should have a long drive home, I started immediately after hreakfist, with the intention of fishing down the river from the farthest point, near Boat o' Brig, to the lowest pool allotted to me for the day. I had killed four very heary salmon a few days before, near the sea, and hardly expected now to surpass my previous good fortune, although perhaps entertaining a vague hope that one of the aforesaid travelling monsters might possibly have halted on his journey and talien up) his quurters in "the Gurlity," or "the Couperee." The weather was everything that could be desired on the Spey. A light southerly breeze curried the distant clonds across the sky, the air was warm, but not oppressive, and the state of the water, when I reached it, appeared epmally propitions. It was lower than duringr the previous week, but ulthough perfectly clear, hat that slight coffee-colonred tint which is so furomralile for sport. On the left hum, just nhove where the burn of Garlity falls in, there is a worded island, separated from the manland by only a compuratively shallow arm, which is casily walcel, lut on the other side, betweon it and l)elfour, a derej amel exoredingly rupid stroam rushes past, which in very low water is gencrally considered a sure lind for a big fish, mud although the river was just now 
too full to give much hope of success at this spot, I could not resist making the attempt; so putting a "purple King" of medium size on a fine double gut casting-line, I tried the entire reach, without a rise or a pull; then changing my fly, but still selecting one of the same size, I repeated the process, wading this time so as to throw into the deepest part of the channel, but was equally unsuccessful. I now adopted a gaudier lure-a "Jock Scott"-but of similar dimensions to the former, hesitating to use a smaller fly and lighter tackle in so violent a stream, where, if taken by a large fish, the struggle would probably end in his escape; but the attractions of "Jock" were unavailing, and even a patient trial of a "silver Doctor"-a regular syren in its way, that had beguiled more than one salmon to its doom-was equally unsuceessful. Below this was Garbity pool, where, two years before, I had capital sport, but on reaching its banks I was not a little disappointed to find its character completely changed. The floods of previous winters had half-filled the bed of the stream with gravel and boulders, and, though of considerable extent, the entire sheet of water was so dull and sluggish that it was impossible to work a fly well in any part of it. Just at the tail, however, the current seemed to concen- 
trate between several rocks and to increase in force until, as a strong boisterous rapid, it joined the hend of the Couperee, one of the most extensive pools on this part of the river. In full water, when just elearing after a spate, heary fisl frequently lie within reach of the left hank, avoiding the more turbulent streum in the mildle, and the best part can be commanded from the shore, lut in its present state they would more probulnly frequent the centrul eurrent, during the upper portion of its course, and it was necessary to wale through a labyrinth of submarged rocks, among which it was no easy matter to adrunce and preserve at the same time a firm footing. Onec imbed I was quite immersed, while feeling my way among the conienl slippery stones at the bottom. Commeneing, us usual, with as large and dull-coloured a fly as seemed suited to the state of the water. and changing it oecasionally from the stoek wommd round my fishing-liat, without going on shore. I deseented erradually from the upper part of the pool until its increasing depth forbute a further progress in that direction. Hore the main anrrent wheeled nearer to the hank, from whenee it appeared quite possible to reach it with a long line for a considemble part of its downwal eomrse, and, feeling rather chilly from my previons duck- 
ing, I was preparing to land, but yielded to the temptation of taking one more cast before doing so. Throwing again therefore across stream, I anxiously watched the fly as it swept round for the last time, but just as I was on the point of drawing it out, a sudden plunge a few inches below it, followed by the apparition of a lnuge dorsal fin above the surface, told that I hand roused the attention of a monster, although he had not yet "tasted steel." To stimulate his appetite therefore by delay I pitched my fly several times higher up, preserving carefully the same length of line, and at last brought it again over him. Every salmon-fisher has experienced the excitement of such a moment, and can sympathize with my feclings after thrice repeating the process in rain. Even a change of fly proved ineffectual, until at last, vexed, shivering, and disappointed, I waded to the shore and sat down sulkily on the lank. Just at that moment the clonds, which lind hitherto floated in succession across the stiy, disappenred one by oue, and for half an hour I lasked luxuriously in the warm smoline, smoked the ealumet of peace, and muler its soothing influence admired the scenery in the neighbonrhoor of this beautiful pool.

Tho the south, aloout a couple of miles off, rose 
the lofty hill of Ben Aigen, rent with two derp clefts, their precipitous sides raried with grey primeral rocks, among which the perenrine faleon still rears its young in spite of constmut persereution, while the farther clifi of the more distunt corrie is covered to the very smmmit of the mountain with dark firs, and the nearer slopes are varied with purple heather and everorren woods, with fissures of sandrock peeping through then, altogether presenting a churmingr contrust of colours in this part of the landscape. Inmedintely opposite were the lesser hills near 1) lf four. (lothed with lareh, spruce, and beech, and only separated by a wide-sprealing bed of shingle from the river, which, after passing through Conperee, turned to the left on its way to Orton, and still further. north the red elifts overhunging its waters near the Chapel pool stood out in bold relief from the gloomy pine forest behimel them.

I had lout little time, however, to spare for admiration even of this picturesque scene. The lack tin of the ligr fish was still fresle in my memory und nppermest in my thounhts. mul I did not yet despuir of becomingr mone intinmely aequinted with hin. I perceived thut the water had fallen considerally since the mominge, nut hat become clearer and more trunsparent, suregesting 
the use of single gut and a much smaller fly than any I had previously used. Carefully turning over every leaf of my book, I had half decided more than once in selecting one, but as often hesitated when I looked at the diminutive barb and thought of the giant in whose jaws I fondly hoped to fix it. Suddenly I recollected that among the larger flies, wound round the cork band encircling my hat, was a very small one, tied but a few days previously for me by that incomparable artist, Shanks, of Craigellachie, on a minute double hook, a few of which I lad procured on my way through London for the express purpose of employing them in clear low water with heavy fish. The little beauty was a modest Spey lassie, known as a "silver green," and not larger than one of the lake trout-flics I had often used in the west of Ireland. The casting-line and termiual loop were of single gut, ly no means thick, but perfectly smooth and cylindrical, every link of which I had previously tested, selecting only a few of the best from ench hank. Now for the trial. I had marked the spot where the fish rose by placing a few stones on the top of the bank immediately opposite, and perceiving that I could reach it without difficulty from the shore, I commenced a little higher up, increasing my 
length of line as I advanced, and nlmost prophetienlly feeling, as I neared it, that the long rest I had given the pool, assisted by the changre of tly and tackle, would rouse him to activity. Yes! he lus it this time. A violent eluck under water that would infullibly have broken any but the very best gut, and whish—sh-sh, away he went like a runaway horse, enrrying off sixty yards of line in a few seconds, townds the fur side of the river. A momentary pause followed, but before I could arail myself of it, another rush succeeded in the same direction, and with dismay I saw that my reel was nearly empty and that my fish was already not far from the spot where $n$ friendnnother piseator, who had just arrived-stood up to his waist in the water at the oppesite side of the pool, awaiting the issue of the combut before commeneing operations himself. Away went the salmon ugain up-stream at it trementous puce, trying to drown the hissing line as it cut its way through the opposing current, and I had to hurry along the bank to outflunk him, cxpecting exery moment before I eould accomplish thut manemve the usual spring into the air, mal that the semersulult, delivered luekwnds, would brenk it - a very probable contingeney under the ciremustumes. But no; he still continued his rupid course muler 
water, now, however, rather in an oblique direction, and as I had by this time got well above him, I was able to wind up quickly, preserving, at the same time, an equal and steady pressure, but, with due regard to the delieacy of my tackle, neither "showing him the butt," nor allowing the rod itself to descend from the perpendieular. Then followed a succession of tremendous rushes, first across, then up, and finally down strean, which last I encouraged by running with him along the bank and leading him, as it were, by gentle force, in the same direction. In this way we traversed nearly the entire length of the pool, but, contrary to my expectation, he showed no sign of exhaustion or change of tactics, and not having yet obtained even a glimpse of him to emable me to guess his weight, I began to think that I had foul-hooked a very heary fish, that his capture would, under any eireunstances, be a work of considerable time, and that if he should continue his present downward course a little longer, and get into the tail of the Couperee, and through a swift and turbulent reach into the Laird's pool, beset with sunken trees and snags, the chances were all against success. Fortunately, lowever, just as these forebodings were on the point of being realized, down he went to the very bottom 
and stopped. Not a moment was now to lie lost. Five minutes' rest would restore all his previous power and activity, but a succession of boulders discharged rapidly and with unerring aim by the hand of Simon, and falling within a foot or two of his position, failed to rouse him from his sulky fit. So winding up quickly and advancing at the same time into the water, rather below my fish, where I found a sound, araselly bottom, I was enalbled to wade within a few yards of the spot, and, with a short line, attempted to lift him, as it were, towards the surface. In thu event of a salmon being foul-hooked this manocure is generally fruitless, but if the fly is fixed within the jaws it is seldom a failure, and, to my clelight, its effect on the present oceasion was instuntaneous. Off he went again towards the other site of the river, and then onee more facel the stresm. Now hurrying out of the water as quickly as possible, and scrambling up the hatnk. I got well above him, and at last I could feel that his strength was becrimning to fuil, as, notwitlustancling the weight, I was able to increase the pressure of the rod without opposition, until I land wemnd up alont forty gards of line spun out during his last run. Now he moved arain submissively down stream, but suddenly, when I least expeeted 
it, made one final desperate effort, and rushed right over to a shallow at the other side of the pool where he had not been before, but quickly yielding to the rod, his back fin and the upper part of his tail appeared above the surface, showing, though but for a few seconds, his enormous proportions, before he rolled heavily into the deep water, as I gradually but steadily drew him towards the shore. Just at this moment I felt almost sure of success, as he was now comparatively reduced to obedience, when an unexpected crisis suddenly arrived.

A little below the fish, but nearer to me, I eaught a glimpse of a small stump-a frament of a submerged tree-projecting above the surfice. In a few seconds all would be over muless I could foree him to this side before the stream carried the line across it. Then, indeed, I rentured-in Irish parlance-to "show him the butt," windingr-np and walking backwards at the same instant, with my heart in my mouth during that trying moment. It was "touch and go." The slighitest effort on the part of the descending griant would lauve ensured his immediate escape, but how ean I describe my delight as he passed between me and the terrible stump, althongh but a few inches from the latter. The rest may be briefly told. The 
donlle hook, though of Lilliputim proportions and severely tested, had proven faithful, and I felt suftieinent confidenee in the nuture and tenarity of its hold to wurrant me in bringingr matters to a speedy conclusion. A few more ineffectunl efforts to retnrn to the stream, and again I led my enptive to the water's edge, where Simon was already cowering under the hank, elip in hand, watehing, like a tiger in his hir, for the smpreme moment. It eame at last. A splash, a plunge, and a fieree strugrale sneceeded, and throwing down the rod, I assisted him in landing an enormons salmon, in heautiful order and of perfeet proportions. Botls larls of the "silver green" wore fixerl inside the mouth, one of them seenrely, while the other hat been eonsiderably bent lonekwards, and had nearly lost its hold. Weight, forty-three pomuls: lemgth, forty-six inches; girth, twenty-six : and, although helieved to be the heariest that had ever heen taken by the rod on Spey, up to that time, yet, in spite of my exultation, I conld not but feel, as the the of war had been eomfined to a single pool, and the enemy hat never shown his colonrs during the battle, that the incilents of the econtest were of a less exeiting eharneter than I had often experienced with many a livelier fish of lessirr weight and inferior comlition. 


\section{A WISII.}

(1II, tell me, kimil angels, why is it. When hundreds of miles far away.

That often in dreams 1 revisit

The banks of the glorious spey :

King David once ruled on the Jordats.

On the Tiber hold Ciesar luad sway.

But Casar was "nocht" " to the (rordon,

And the Tiler a joke to the Nieg.

And the Amazon, Nile, and kiuphrates,

Are all very well in their way,

And the Sbannon in land of "pitatees,"

but none can compare with the Srey.

Such fishing: liy Jupiter Ammon.

There's nothing like fishing, 1 saty,

And especially fishing for sil inon

In the pools of the galloping sirey.

Six weeks from the First of Septenber

Bver pass like one heatiful day.

Tis a time I shall ever remomber,

A paradise passid on the siey.

If l've any particular wisls

Since my hair has grown grizolerl and grey.

Why it in to le sible to fish

Hery year till 1 die, in the sipey.

- Necht-nihil. Iamesos s llietionary of the Serotlish Lan. yuury. 
Ind when the grim tyrand draw - near.

Anl lifes breath is ebling away, May all that is left of me here

Repose on the hanks of the Spey.

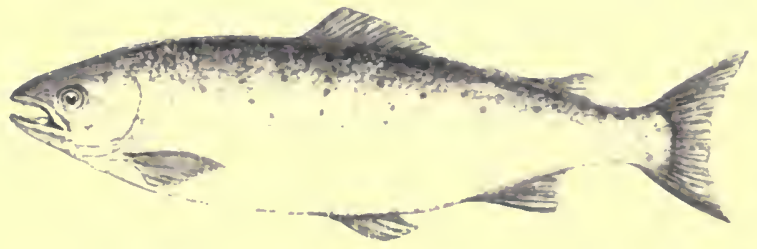

Wiondfall and Kinder, Printen, Milforl tane, straml. Inivel,s, W: 


University of California

SOUTHERN REGIONAL LIBRARY FACILITY

405 Hilgard Avenue, Los Angeles, CA 90024-1388

Return this material to the library from which it was borrowed.

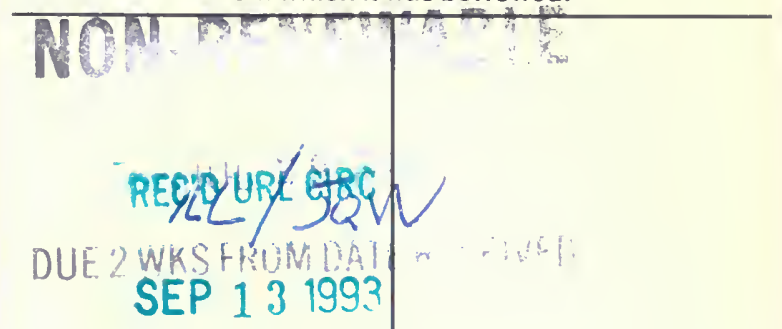

THE LIBRARY 
byำ

Univer Sou 